\title{
THE UNPRINCIPLED USE OF ORIGINALISM AND SECTION 24(2) OF THE CHARTER
}

\author{
Daniel C. Santoro*
}

Twenty years ago, the Supreme Court of Canoda laid the foundation to the modern appronch of the exclusion of evidence unders. 24(2) of the Charter in R. v. Collins. The anthor examines the treument of this test by the Supreme Court in the subsequent cases of R. v. Burlingham and R. v. Stillman, with particular attention paid to the majority's rationale in Stillman for creating an "exclusionary rule" for conscriptive non-discoverable evidence. The author examines the crisical debate surrounding Stillman, focusing on the argument that it was comtrary to the "originat intentions" of the draffers of the section. The anthor challenges this argumen with four major assertions and then proceeds to examine recent attempts to reformulate the Stillman test. The author conludes that the rationale underlying the Stillman test was clearly and powerfully articulased. Any move to change the law' must confrom this rationale.
Ily a vingl ans. la Cour suprème du Cimsudajeta les assises d'une approche mederne a liexchusion d'une preme en versu de l'article 24(2) de la Charte dans R. c. Collins. $L$ 'ameere examine le traikement de ce rest par la Cour supreme doms les causes subsiquentes, is savoir R.c. Burlingham et R. c. Stillman, en accordant une attention spiciale à la justification de la majorité dans Stillman pour créer une "règle dexchusion" dans le cas d'une prewe non decounrable, obtemue en mobilisanl accusé contre hi-même. L' auteur examine le débat crifique aurour de Stillman, en insistant sur l'argument que c'ícail contraire atax "intemtions origimules " de ceur qui anaient ridlige cet article. L'auteur comesfe largument an moven de quatre grandes affirmations. pais examine les récentes tentatives de reformuler le test de Stillman. L.'auteur conclu que la justification sous-jaceme du sest de Stillman arait ife présentée de maniere claire et puissante. Toute remative de modification de la loi doit aborder cette justification.

\section{TABLE OF CONTENTS}

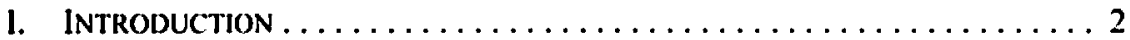

II. THE SUPREME COURT ON SECTION 24(2): AN OVERVIEW $\ldots \ldots \ldots \ldots \ldots 3$

A. THE ChIARTER ........................... 3

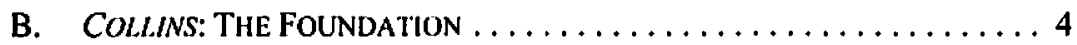

C. BURLINGHAM: AN INTENSE DEBATE $\ldots \ldots \ldots \ldots \ldots \ldots \ldots \ldots$

D. StILlMMAN: THE LEADING CASE $\ldots \ldots \ldots \ldots \ldots \ldots \ldots \ldots$

III. Dissenters AND CRITICS: REliANCE ON THE.

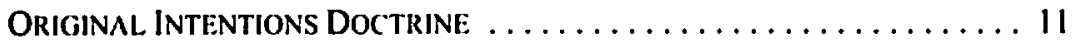

IV. THE "ORIGINAL INTENTIONS" OF THI: DRAFTERS:

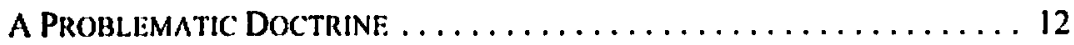

A. ORIGINALISM AND PROGRESSIVISM AS INTERPRITIVE DOCTRINE $\ldots 13$

B. THE REJECTION OF ORIGINALISI $\ldots \ldots \ldots \ldots \ldots \ldots \ldots \ldots \ldots \ldots$

C. THE FICTIONAL INTENTION OF THE DRAFTERS $\ldots \ldots \ldots \ldots \ldots 20$

D. Progressive VS. FROZEN INTERPRETATIONS OF CHARTER RIGHTS . 27

E. THE NECESSITY OF A PROCiRESSIVE INTERPRETATION

OF SECTION 24(2) ......................... 28

V. OPENING THE BACK DOOR TO CONSCRIPTIVE EVIDENCE:

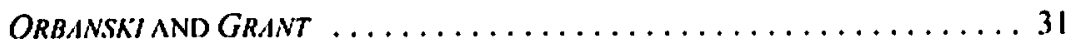

A. The "Plain Meaninci" of Section 24(2)? ............. 31

B.A., LL.B., Osgoode Hall Law School. York University, member of the Ontario Bar. The author wishes to thank Prolessor Marilyn Pilkinton lor her guidance and Nicolas Rouleau for his helplul comments. 

B. ORbANSKI: ThE FACTS $\ldots \ldots \ldots \ldots \ldots \ldots \ldots \ldots \ldots \ldots \ldots \ldots$
C. THE ADMISSIBILITY OF THE EvidenCE $\ldots \ldots \ldots \ldots \ldots \ldots \ldots \ldots$

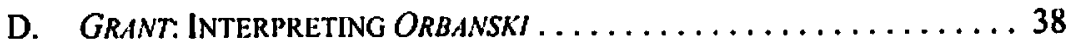

vi. ConCLUSION ........................... 40

\section{INTRODUCTION}

At the core of every criminal trial lies the tension between the legal rights of the individual accused of a crime and the power of the state launched against that individual to seek a conviction. It often happens that the state oversteps the permissible bounds of investigative conduct and violates the rights of the accused person. Section 24(2) of the Canadian Charter of Rights and Freedoms' provides a remedy for such violations: the state is not permitted to use the illegally obtained evidence against the accused person during his trial if to do so would bring the administration of justice into disrepute. The repercussions of this doctrine are enormous, the starkest example being when reliable evidence that inexorably points towards a conviction is excluded and an acquittal is entered instead. It should therefore come as no surprise that s. 24(2) of the Charfer attracts an enormous amount of legal commentary and argument.

The Supreme Court of Canada's current approach to the exclusion of illegally obtained evidence under s. 24(2) of the Charter has been the object of harsh and pointed criticism. The Court clarified the appropriate test to be applied in the case of $R$. $v$. Stillman, ${ }^{2}$ affirming the line of jurisprudence that had developed since $R$. $v$. Collins, ${ }^{3}$ the highly criticized case which continues to form the foundation of s. 24(2) analysis. The Stillman decision was hotly anticipated at the time, as many hoped that the Court would re-evaluate its approach to the exclusion of illegally obtained evidence. The majority of the Court refused, however, to revamp its interpretation, and Stillman was thus received by many with less than a warm welcome. The criticisms leveled against the Collins regime persisted, launched anew against Stillman. Nine years later, it is now entirely possible that the Supreme Court may re-evaluate its s. 24(2) jurisprudence for the new millennium; the critics may yet prevail.

In a s. 24(2) analysis under Stillman, the illegally obtained evidence is first classified as conscriptive or non-conscriptive depending on whether or not the accused was compelled during its creation or discovery. Conscriptive evidence that is not othenvise discoverable is almost always excluded. If the evidence is not conscriptive, a more comprehensive balancing process is undertaken in order to determine the effect on the repute of the administration of justice that would flow from the admission or exclusion of the evidence.

The most vehement criticism of the approach taken in Stillman is directed against the absolute exclusionary rule for conscriptive evidence. There is one argument in particular that seems to be strong and objective: the judicial interpretation of s. 24(2) found in Stillman is a distant cry from the original intentions of the drafters of the Charter. Section 24(2) was to

Part I of the Constitution Act, 1982, being Schedule B to the Cuncula Act 1982 (U.K.), 1982, c. 11 [Charter]. 
be a compromise between the American exclusionary and common law inclusionary positions, and Stillman is far too close to the American position. This criticism is based on the "original intentions" doctrine of constitutional interpretation.

This article outlines, however, that the spirit of such criticism is incompatible with a strong and progressive view of the Charter. Section 24(2) should be approached with the same spirit that the Supreme Court has applied in interpreting the other sections of the Charter. First, originalism as a constitutional interpretive doctrine has been consistently rejected by the Supreme Court. There is no reason why originalism should be used to interpret s. 24(2) when it is not used to interpret the rest of the Constitution. Second, it is a fiction to suppose that there is a clearly discernible intention behind s. 24(2) or any other section of the Constitution. It will be historically demonstrated that there is in fact no such intention; rather, s. 24(2) was the result of a great deal of conflict, and is best seen as an expression of a continually evolving approach to the exclusion of evidence. Third, even if there were a clearly discernible intention behind s. 24(2), there is no good reason why courts should forever be bound by that intention if it is not explicitly entrenched in the language of the section as drafted. Section 24(2), along with the rest of the Constitution, should be interpreted purposively and progressively. Last, some of the implications of applying a progressive view of constitutional interpretation to s. 24(2) will be outlined. Progressivist interpretation allows the permanent words of the Constitution to adapt to changing needs and increasing knowledge. It will be argued that progressivism is far preferable to originalism when both doctrines are seen in the light of our post-Charter understanding of the criminal justice system. Given recent judicial observations, originalism is a particularly inappropriate doctrine to apply when interpreting s. 24(2).

The recent decision of the Supreme Court in $R$. v. Orbanskit has rekindled the s. 24(2) debate. In brief concurring reasons, LeBel J. purports to simply reiterate the law established since Stillman. His explanation of s. 24(2), however, represents a marked departure from prior jurisprudence. It will be argued that LeBel J. is endorsing a "plain meaning" interpretation of s. 24(2), an approach which was effectively rejected in both Stillman and R. v. Burlingham. Stillman proposes a doctrine that is consistent with and founded in strong libertarian policy considerations. Illegally obtained conscriptive evidence violates one's right against self-incrimination, which is an essential cornerstone to trial faimess. Any departure from its rationale demands a strongly reasoned response grounded in sound policy considerations. The Orbanski decision has not met this high burden.

\section{The Supreme Court on SeCtion 24(2): AN Overview}

\section{A. THE CHARTER}

The Charler constitutionally entrenches several legal rights which go to the core of the Canadian criminal justice system. Section 8 guarantees "the right to be secure against unreasonable search and seizure," $s$. 9 guarantees "the right not to be arbitrarily detained and imprisoned," and s. 10(b) guarantees "the right to retain and instruct counsel without delay 
and the right to be informed of that right." If evidence is found to have been obtained in contravention of these, or any other sections of the Charter, a remedy may then be available under s. 24(2):

Where, in proceedings under subsection (1), a court concludes that evidence was obtained in a manner that infringed or denied any rights or freedoms guaranteed by this Charter, the evidence shall be excluded if it is established that, having regard to all the circumstances, the admission of it in the proceedings would bring the administration of justice into disrepute.?

\section{B. COLLINS: THE FOUNDATION}

In Collins, the Supreme Court set out the analytical framework to be applied under s. 24(2). Though decided in 1987, it remains the foundational s. 24(2) case. Ms. Collins was sitting down in a pub when a police officer suddenly seized her by the throat, using considerable force, and pulled her down to the floor. The oflicer then discovered that Collins was holding a green balloon containing heroin in her hand. The throat hold is a technique used by police to prevent narcotics traffickers from swallowing their drugs, and is a common practice. The trial record did not reveal reasonable grounds for this search. The Supreme Cour thus held it to be in violation of $\mathbf{s .} 8$ of the Charler, and turned its attention to the exclusion of evidence under s. $24(2){ }^{3}$

If the applicant whose rights have been violated establishes, on a balance of probabilities, that the admission of the evidence would bring the administration of justice into disrepute, the trial judge must exclude the evidence. The Court points out that s. 24(2) is not a remedy for police misconduct. The test is not whether the misconduct by which the evidence was obtained would bring the administration of justice into disrepute. Rather, the question is whether the admission of the evidence into the proceeding would bring the administration of justice into disrepute. It is noted, however, that disrepute can result from judicial condonation of unacceptable police conduct. ${ }^{9}$

The s. 24(2) inquiry is to be forward-looking and objective. The court is to focus on "the long-term consequences of regular admission or exclusion of this type of evidence on the repute of the administration of justice." opinion: "The Charter is designed to protect the accused from the majority, so the enforcement of the Charter must not be left to that majority." The Court adopts the test proposed by Yves-Marie Morissette: "Would the admission of the evidence bring the administration of justice into disrepute in the eyes of the reasonable man, dispassionate and fully apprised of the circumstances of the case?"'2

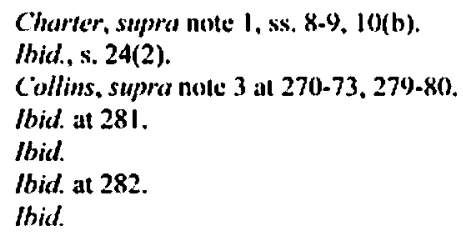


Within this general approach, Lamer J. formulates a more concrete analytical framework. Under s. 24(2), the judge must look at "all the circumstances," a process which involves considering and balancing several factors, which are in turn grouped "according to the way in which they affect the repute of the administration of justice." 13 While Lamer J. says that this grouping is merely "a matter of personal preference," 14 it has become historically enshrined as the central feature of the Collins test.

First, there are factors which tend to prove that the admission of the evidence in question may affect the faimess of the trial. Such evidence should generally be excluded. The right to a fair trial is guaranteed in s. 11 (d) of the Charter, and is central to our criminal justice system. Justice Lamer explains what sort of evidence might affect trial fairness:

Real evidence that was obtained in a manner that violated the Charter will rarely operate unfairly for that reason alone. The real evidence existed irrespective of the violation of the Charter and its use does not render the trial unfair. However, the situation is very different with respect to cases where, after a violation of the Charter, the accused is conscripted against himself through a confession or other evidence emanating from him. The use of such evidence would render the trial unfair, for it did not exist prior to the violation and it strikes at one of the fundamental tenels of a fair trial, the right against self-incrimination... It may also be relevant, in centain circumstances, that the evidence would have been obtained in any event without the violation of the Charter. ${ }^{15}$

Thus, conscripted evidence will generally be excluded because it taints the faimess of the trial. Real evidence that existed prior to the Charfer breach will not generally affect trial fairness, and the court must go on to consider other factors.

The second set of factors pertain to the seriousness of the Charter breach, "and thus to the disrepute that will result from judicial acceptance of evidence obtained through that violation." whether it was inadvertent or of a merely technical nature, whether it was deliberate, willful or flagrant, and whether it was motivated by urgency or necessity to prevent the loss or destruction of evidence. Justice Lamer strongly asserts that the availability of other licit investigatory techniques by which the evidence would have been obtained "tends to indicate a blatant disregard for the Charfer, which is a factor supporting the exclusion of the evidence." 17

The third and final group of factors go to any disrepute to the system that would result from the exclusion of evidence. Here, the judge must balance the seriousness of the Charter breach, the importance of the evidence obtained, and the seriousness of the alleged offence. The seriousness of the offence, however, is not a factor which can override unfairness in the trial process. 
On the facts of the case, the Court finds that the evidence was real, did not emanate from the accused, and therefore would not affect trial fairness. However, the Court reasons, while the cost of excluding the evidence is high in the sense that Collins may evade conviction on a relatively serious charge, the cost of admitting the evidence is also high because of the seriousness of the breach. A court must "dissociate itself from the conduct of the police in this case which ... was a flagrant and serious violation ... [W]e cannot accept that police officers take flying tackles at people and seize them by the throat when they do not have reasonable and probable grounds." 18 The matter was therefore sent back for a new trial, in order to determine whether the officer in fact had reasonable and probable grounds.

\section{Burlingham: AN INTENSE Debate}

The Collins decision quickly became the object of much harsh controversy. Critics argued that the conscriptive/real evidence distinction under the first branch of Collins factors was untenable: ${ }^{19}$ the court was unreasonable in crafting an absolute exclusionary rule for conscriptive evidence. Such criticism was not merely academic, but came to be shared by members of the Supreme Court itself.

In Burlingham, L'Heureux-Dubé J. wrote a fiery dissent: it was so powerful, in fact, that it procured a direct and pointed response from Sopinka, Cory, lacobucci, and Major JJ. The facts of the case will not be recounted here as the intense debate surrounding the nature of the exclusionary rule is what is most relevant for the purpose of this article. Disputing the conscriptive/non-conscriptive evidence distinction, L'Heureux-Dubé J. proposed another set of criteria by which trial faimess ought to be determined:

Section $24(2)$ of the Chorfer was not enacted in a vacuum. As numerous commentators have noted, it reflected a compromise between a Canadian common law rule which focused almost exclusively on reliability and an American exclusionary rule which focused largely on police misconduct. It was intended as a cautious expansion of the Canadian common law.... In my vicw, at the heart of $R . v$. Collins ... is the recognition of two fundamental concerns, the encroachment of either of which could bring the administration of justice into disrepute within the meaning of s. 24(2).

The first basic concem groups together all of the common law and Charter protections of the accused that ultimately relate to liberty and truth-secking. For the sake of simplicily, I shall call it the "Reliability Principle”. In essence, this principle dictates that our justiec system must be constantly and intensely vigilant to ensure that innocent persons not be convicted... Accordingly, under the Reliability Principle, the use at trial of evidence, obtained in a manner that violated the Charer, that may mislead the trier of fact could render that trial unfair, and could bring the administration of justice into disrepute.... In orher words, where the unfairness flowing from the Charter violation man' touch in amy way upon the actual adjudicative process. then this kind of evidence must almost inevitably be excluded.

The second basic concern relates to life, security of the person and, within that same rubric, fundamental human dignity. For the sake ol' convenience, I shall refer to this principle as the "Fuimess Principle". This principle groups together all of the common law and Charfer protections that breathe life into the notion that 
the individual should be free from unwarranted interference with the state. In essence, it recognizes the vital importance in ensuring that the state treat each individual in accordance with basic principles of decency and fair play....

These two fundamental concerns reflect, in my view, the "principles underlying the principles".

To summarizc, given that this Coun uses "trial faimess" within s. $24(2)$ as a proxy for circumstances in which the administration of justice is almost inevilably brought into disnepute, and where any other mitigating considerations or circumstances are vinually irrelevant, I believe that it is most consistent with the purpose and spiril of s. 24(2) to define that calegory of factors narrowly. In my respectful view, it runs counter to the inherently discretionary nature of a s. 24(2) determination, which is to be made "having regard to all of the circumstances", to formulate rigid rules or presumptions for the exclusion or admission of different kinds of evidence. Thus, to the extent that this Court decides to set down such a rule in regard to "trial faimess". I believe that it should take care not to define that concept so broadly as to allow the "trial faimess" tail to wag the s. 24(2) dog. ${ }^{20}$

Justice Sopinka (Cory, lacobucci, and Major JJ. concurring) wrote a separate concurring judgment solely for the purpose of addressing L'Heureux-Dubé J.'s argument in which they strongly defended the conscriptive/non-conscriptive evidence distinction and its foundation in the right against self-incrimination:

Whether it was ever so intended, it soon became apparent that real cvidence and evidence cmanaling from the accused were not mutually exelusive cullegories of evidence, and in $R$. v. Ro.s. [ [989] I S.C.R. 3, Lanter J. explained at p. 16 that:

the use of any evidence that could not have been obtained but for the participation of the aceused in the construction of the evidence for the purposes of the trial would tend to render the trial process unfair.

The rationale for this view is that it is unfair for the Crown to make out its case in whole or in part by the use of evidence that it obtained in breach of the rights of the accused and involving his or her participation. La liorest J. addressed this point in Thomson Newsyopers l.td. v. Canada (Director of hmestigation and Research, Restrictive Trade Practices Commission), [1990] I S.C.R. 425, stating at p. 553:

\begin{abstract}
A breach of the Charter that forces the eventual accused to create evidence necessarily has the effect of providing the Crown with evidence it would not otherwise have had. It follows that the strength of its case against the accused is necessarily cnhanced as a result of the breach.... In contrast, where the effect of a breach of the Charter is merely to locate or identify already existing evidence, the case of the ultimate strength of the Crown's case is not necessarily strengthened in this way. The foct that the evidence atready existed means that it condd have been discovered anywy. Where this is the case. the accused is not forced to confront any evidence ar trial that he would not have been forced to confrom if his Charter rights had been respected.
\end{abstract}


The participation of the accused in providing incriminating evidence involving a breach of Charter rights is the ingredient that tends to render the trial unfair as he or she is not under any obligation to assist the Crown to secure a conviction. ${ }^{21}$

Justice Sopinka specifically criticized the reliability of the evidence as a factor relevant to trial faimess:

Specifically, [L'Heureux-Dube J. J does nol criticize the principle that the admission of evidence that would render the trial unfair would bring the administration of justice into disreputc.... My colleague's criticism is with respect to the kind of evidence that can result in an unfair trial. in her view, only the admission of evidence that is not reliable by reason of some connection with state action amounting to a Charrer breach can render the trial unfair (the "reliability principle")....

I have great difficully in apprecialing how the application of these two principles as suggested by my colleague constitutes a return to Collins. Nowhere in Collins is the faimess of the trial equated with the reliability of the evidence... [The reliability principle's] precceupation with the probative value of the evidence would also appear to be a close relative of the rule in R. v. Wray, [ [97I] S.C.R. 272. At page 293, Marlland J. stated:

the exercise of a discretion by the trial judge arises only if the admission of the evidence would operate unfairly. The allowance of admissible cvidence relevant to the issue before the court and of substantial probative value may operate unfortunately for the accused, but not unfairly. It is only the allowance of evidence gravely prejudicial to the accused. the admissibility of which is tenuous, and whose probative force in relation to the main issue before the ceur is trifling. which can be said to operale unfairly.

Wray' was widely criticized, has not been followed by this Court and was not the basis for the exclusionary power adopted by the Charter in s. 24(2). ${ }^{22}$

Since a fair trial is the sine qua non of our justice system, an unfair trial necessarily brings the administration of justice into disrepute. Compelling an individual to produce evidence against himself violates the right against self-incrimination which is the cornerstone of trial fairness. This principle holds whether or not the evidence obtained is reliable. According to L'Heureux Dubé J., though, since s. 24(2) was not intended to be an automatic exclusionary rule, this dichotomy is too broad. Unreliable evidence is the only kind of evidence subject to an automatic exclusionary rule.

\section{Stillman: Tue Leading CASE}

The Supreme Court's decision in Stillman was hotly anticipated. As Carol A. Brewer from the Crown Law Office - Criminal, Ministry of the Attorney General of Ontario explains:

On May 23. 1996, several montlis aller hearing argument and reserving its decision, the Court ordered a rehearing and expressed a willingness to reconsider the established principles in relation to the application of 
section 24(2) of the Charter. As a consequence, II parties sought and were granted [intervener] status in order to participate in a case which was seen as "the Collins of the $90 \mathrm{~s} . .23$

The majority reasons written by Cory J. largely affirmed and clarified the Collins framework. Justice McLachlin, as she then was (Gonthier J. concurring), and L'Heureux-Dubé J., however, wrote strong dissenting reasons.

Mr. Stillman, who was 17 years old, had been accused of the brutal murder of a 14-yearold girl. The girl had been found in a river, six days after she had last been seen walking away into the night with Stillman. She had semen in her vagina and a bite mark on her abdomen. The autopsy revealed that she had been killed by wounds to the head. Stillman was arrested for her murder and was brought into the police station. Defence counsel spoke with him for over two hours, and upon leaving the station, provided written instructions to the police that Stillman had been advised not to say anything, and not to consent to provide any bodily samples. Once the lawyers had left, however, the Royal Canadian Mounted Police (RCMP) took hair samples and teeth impressions. Stillman was required to pull out some of his pubic hair. All of this was done under threat of force. The RCMP interviewed Stillman for over one hour, during which he said nothing, but sobbed, blew his nose and threw the tissue into the garbage. Stillman was not charged and was subsequently released because the police had insufficient evidence against him. The RCMP recovered the tissue and submitted it for DNA testing. After receiving the results of the test, the RCMP once again arrested Stillman, brought him into the station, and forcibly took another set of teeth impressions as well as a buccal swab. The trial judge held that the Stillman's Charrer rights had been violated, but admitted the evidence under s. 24(2). Stillman was convicted by a jury of first degrec murder. ${ }^{24}$

The majority of the Supreme Court of Canada, after lengthy analysis, concluded that all the evidence taken by the RCMP was obtained in violation of the Charter, and so turned its attention to admissibility under s. 24(2). Justice Cory made it clear from the outset that the main issue to be decided in Stillman was the nature of the trial faimess branch of the Collins test. ${ }^{25} \mathrm{He}$ begins by explaining the importance of trial fairness:

A consideration of trial faimess is of fundamental imporance. If after carcful consideration it is determined that the admission of evidence obtained in violation of a Churter right would render a trial unfair then the evidence must be exeluded without consideration of the other Collins faters. A lair trial for those aceused of a criminal offence is a comerstone of our Canadian democratic society. A conviction resulting from an unfair trial is contrary to our concept of justice. To uphold such a conviction would be unthinkable. It would indeed be a travesty of justice. The concept ol trial faimess must then be carefully considered for the benefit of society as well as for an accused. ${ }^{26}$ 
The "primary aim and purpose" of trial fairness is to uphold the cornerstone right against self-incrimination. The ultimate purpose is:

...10 prevent an aceused person whose Charter rights have been infringed from being loreed or conscripled to provide evidence in the form of statements or bodily samples for the benefit of the state. It is becunse the accused is compelled as a result of the Churter breach to participate in the creation or discovery of selfincriminating evidence in the form of confessions, stalements or the provision of bodily samples, that the admission of that evidence would generally lend to render the trial unlair. "2

Justice Cory neally lays out the framework for a s. 24(2) analysis. First, the evidence is to be classified as conscriptive or non-conscriptive. Evidence is conscriptive if the accused is compelled as a result of a Charter breach to participate in the creation or discovery of selfincriminating evidence in the form of confessions, statements, or bodily samples. Conscriptive evidence will be excluded unless the Crown establishes, on a balance of probabilities, that the evidence would have been discovered by alternative and nonconscriptive means. If the Crown cannot do this, the court will exclude the evidence without considering the other two branches of the Collins test: "This must be the result since an unfair trial would necessarily bring the administration of justice into disrepute." ${ }^{28}$ If the evidence is either non-conscriptive or discoverable conscriptive evidence, the cour must then consider the seriousness of the breach and the effect of exclusion on the repute of the administration of justice.

On the facts, the DNA evidence derived from the discarded tissue was admitted as nonconscriptive evidence which passed the remaining Collins threshold. However, the court exciuded all the hair, bite, and buccal samples. They were obtained by coercive police conduct, described by the court as abusive and capable of shocking the conscience of the community. The Charter is for everyone, even accused criminals, and police cannot simply override the Constitution in order to further an investigation.

The rationale behind the exclusionary rule for conscriptive evidence in Stillman can be supported by the following basic argument. Though it is not explicitly articulated as such, it is submitted that this rationale clearly underlies the reasoning process in Stillman and Burlingham:

(1) Where, contrary to the Charter, an accused is compelled or conscripted to produce evidence against himself in the form of statements or bodily samples, the admission of that evidence violates the right against self-incrimination.

(2) The right against self-incrimination is the comerstone of a fair trial. Thus, when evidence obtained in violation of this right is admitted into a trial, the trial becomes unfair.

(3) An unfair trial necessarily brings the administration of justice into disrepute. 
Conscriptive evidence must therefore be excluded because its admission would violate selfincrimination, render the trial unfair, and bring the administration of justice into disrepute.

\section{Dissenters AND CRITICS: \\ RELIANCE ON THE ORIGINAL. INTENTIONS DOCTRINE.}

The majority's interpretation of s. 24(2) of the Charter in Stillman has been the object of much criticism originating not only from academic circles, but also from the bench of the Supreme Court itself. In particular, the exclusionary rule for conscriptive evidence has been harshly attacked. The strongest argument seems to be firmly grounded and objective, and is based on the "original intentions" doctrine of constitutional interpretation.

The allegation that the majority's interpretation of s. 24(2) ignores the intentions of the drafters of the Charter is pervasive. David Paciocco explains that s. 24(2) was intended to be a compromise between the quasi-American absolute exclusionary rule and the traditional common law inclusionary rule:

The rejection of the polar extremes has been drafted into the provision... The spirit of the provision, if not its very language, calls into question the legitimacy of developing even quasi-automatic principles for exclusion. Despite this, the court has produced just such a principle, and its implications are enormous. ${ }^{29}$

Carol A. Brewer similarly reminds her readers that s. 24(2) was intended to be a compromise provision. In her argument against the absolute exclusionary rule for conscripted evidence, she implies that Stillman is not faithful to the spirit of the provision. ${ }^{30}$ Likewise, Julianne Parfett, Assistant Crown Attorney in Ontario, criticizes the Court's approach, arguing that the philosophy of liberalism has unduly influenced s. 24(2) doctrine, which though "[o]riginally conceived as a compromise ... has in fact developed into a quasi-automatic exclusionary rule." ${ }^{31}$ Adam M. Parachin makes a similar argument, supported by a detailed historical analysis of the provision. ${ }^{32}$ Justice Michel Bastarache commented in an interview to the Lawyer's Weekly shortly after his appointment to the Supreme Court of Canada about the conscriptive evidence analysis in Stillman:

I don't think there is any legal support for that. I think it is an invention of the Court, a principle that was created by the Court, and I think it's inconsistent with the very wording of [the Charter], with the intention of Parliament [...] and I also think it's totally unrealistic. ${ }^{33}$

David M. Paciocco, "The Judicial Repeal of s. 24(2) and the Development of the Canadian Exclusionary Rule" (1989-90) 32 Crim. L.Q. 326 at 354 [emphasis in original].

Brewer, supra note 23 at 240-41.

Julianne Parfet, "A Triumph of Liberalism: The Supreme Court of Canada and the Exclusion of" Evidence" (2002) 40 Alta. L. Rev. 299 at 300.

2. Adam M. Parachin, "Compromising on the Compromise: The Supreme Court and Section 24(2) of the Charrer" (2000) 10 Windsor Kev. L.egal Soc. Issues 7.

"The Complaint against Michel Bastarache" For the Defence: Criminal Lawyers'Association 22:1 (January/february 2001) 1 at 3 . These comments occasioned a complaint by the Criminal Lawyer's Association to the Canadian Judicial Council as contravening the Council's "Eihical Code for Judges." 
Justice McLachlin forcefully articulates a form of this argument in her dissenting reasons in Stillman. "Section 24(2) of the Charter," she asserts, "may be seen as a compromise between the 'automatic exclusionary' rule of the United States, and the 'no exclusion' rule prevailing in Canada in 1982 prior to the Charter's adoption." ${ }^{35}$ However, after reviewing the history of the section and the Court's earlier decisions, she concludes that, "the framers of the Charter did not intend s. 24(2) to act as an automatic exclusionary or quasiexclusionary rule. ${ }^{36}$ With respect to the absolute exclusionary rule for conscriptive evidence affirmed by the majority of the court in Stillman, "[i]t is apparent that this approach is the antithesis of the balancing envisioned by the framers of s. 24(2)." ${ }^{37}$ Justice McLachlin argues for an elimination of this dichotomy: the Court should undertake a comprehensive balancing of all relevant circumstances in deciding whether to exclude illegally obtained evidence. This approach, unlike that of the majority, "avoids the automatic exclusionary rule eschewed by the framers of the Charter." ${ }^{38}$ Thus, McLachlin J.'s dissenting reasons are underpinned with the call for faithfulness to the original intentions of the drafters of s. 24(2).

This view is also strongly articulated by L'Heureux Dubé J. in her dissent in Burlingham. Section 24(2), she says, "was not enacted in a vacuum.... It was intended as a cautious expansion of the Canadian common law." ${ }^{39}$ She characterizes it as a compromise provision, and holds that the Supreme Court has a duty to remain faithful to its spirit and purpose. Citing Professor Paciocco, she asserts that "this Court's evolving jurisprudence on s. 24(2) has failed to effect this balance, and has therefore been unfaithful to its constitutional mandate under that section."

\section{THE "ORIGiNAL, INTENTIONS" OF THE DRAFTERS: A Probi.ematic Doctrine.}

An "original intentions" style argument is widely and strongly made by both academic and judicial critics. ${ }^{41}$ The essential argument is that $\mathrm{s}$. 24(2) was not intended to be an exclusionary or quasi-exclusionary provision. Nevertheless, in its evolving jurisprudence, the Supreme Court has crafted an absolute exclusionary rule for conscriptive evidence. This is an illegitimate development which is not in accordance with the original intentions of the drafters of the section. Peter Hogg describes "originalism" as the argument "that a court is bound by the "original understanding' of a constitutional text," great weight to legislative history of constitutional provisions and the intentions of its framers. In using the intentions of the drafters of the Charter and the legislative history of

Justices L'Heuruux Dubé and Gonthicr express their agrecment with this aspect of McLachlin J.'s judgment: see Sillman, stupra note 2 at paras. 183, 193.

Jbid. at para. 236.

lbid. at para. 244.

Ibid. at para. 245.

Ihid. at para. 258 .

Burlingham, supro note 5 at para. 84.

Ihid. at para. 73.

This is not to say that this is the only or the strongest criticism being made. It is simply pointed out that the "original intentions" argument is popularly and vigorously made. It is perhaps a safe conclusion that this originalist spirit underlies much of the existing criticism, implicitly if not explicitly.

Peter W. Hogg, Constitutional Lon' of Canada, 4th ed., looseleaf (Scarborough: Carswcll 1997) vol. 2 at 57.7 . 
s. 24(2) to bolster an argument for a certain judicial interpretation, McLachlin C.J.C., L'Heureux-Dubé, and Gonthier JJ., as well as Professor Paciocco and others are clearly espousing a form of originalism, or the doctrine of the original intentions.

There are numerous problems with the original intentions doctrine in general, and in particular, with using it to interpret s. 24(2) of the Charter. First, originalism has been repeatedly and forcefully rejected in Canadian jurisprudence. Second, it is a fiction to suppose that there is an actual intention behind a constitutional provision. It will be historically demonstrated that there is no discernible intention behind s. 24(2); rather, s. 24(2) developed from a great deal of controversy and was drafted with deliberate generality. Third, even if such an original intention could be discerned, there is no good reason why courts should be forever bound by a particular interpretation simply because it was what the drafters of the provision had in mind. This would have the effect of freezing-in-time a particular legal view. Contrary to this, the Supreme Court has adopted a progressive view of constitutional interpretation. Just as the common law exclusionary rule has continued to evolve, so should the constitutional remedy under s. 24(2). Fourth, since the enactment of the Charter, indeed, partially because of the enactment of the Charter, our knowledge of the workings of the criminal justice system has increased dramatically. This new and continually developing knowledge mandates a progressive interpretation of s. 24(2) and, accordingly, an evolving jurisprudence. In this light, it will be shown that an originalist interpretation of $s .24(2)$ is particularly inappropriate.

\section{A. Originalism and Progressivism as Interpretive. Doctrine:}

Before dealing with the doctrine of originalism as it pertains to s. $24(2)$ of the Charter, it will be useful to review the originalist and progressivist philosophies of constitutional interpretation. Originalism is a doctrine that is capable of inspiring cogent critiques of progressivist interpretive doctrine, many tenets of which would likely otherwise go unquestioned. Furthermore, originalism makes a serious philosophical claim to political legitimacy that demands a response. Originalism is, however, problematic on both a theoretical and practical level. The theoretical problems with originalism will be briefly discussed in this section of the article, to be followed by a practical demonstration of how these problems play out with respect to s. 24(2) of the Charter. However, since originalism presents a compelling case against unfettered progressivism. it will be argued that a form of progressivism that is bound by a careful adherence to the text, with due reference made to philosophical and historical context, is the most preferable school of constitutional interpretation. The practical implications of this doctrine will, again, be examined with respect to s. 24(2) of the Charter.

Antonin Scalia, Associate Justice of the Supreme Court of the United States, describes his approach to originalism, "the basic tenets of which are twofold: (1) adhere to text; and (2) give text the meaning it bore when it was adopted." ${ }^{33}$ He makes the staggering claim that because the Supreme Court does not feel itself bound by either the text or the historical practices of the American people that "under the Supreme Court's current jurisprudence, the

4Justice Antonin Scalia, "Romancing the Constitution: Interpretation as Invention" (2004) 23 Sup. Ct. L. Rev. (2d) 337 at 337 . 
U.S. Constitution contains whatever unenumerated rights the Supreme Court believes it ought to contain." ${ }^{44}$ He claims that this is completely inconsistent with democratic society:

It is of no more use for an American to try to persuade his fellow citizens that abortion should be prohibited, that un-Mirandized confessions should be admissible, or that homosexual acts should be unlawful. than it is to try to persuade them that the free exercise of religion should be prohibited. Those issues have been placed beyond democratic control by the Constitution - the last by the real Constilution. and the first three by a constitution invented by the Supreme Court. Of course, when the real constilution placed it beyond democratic control, it did so only because a democratic majority had agreed to be disenfranchised with regard to those subjects. No one has agreed to be disenfranchised with regard to the constitutional prohibitions invented by the Supreme Court. ${ }^{45}$

The logical extension of this argument, according to Scalia, is that the Supreme Court loses its democratic legitimacy when it makes itself (and not the people) the author of the Constitution:

\begin{abstract}
The people are not stupid. When the primary function of the Supreme Court was thought to be interpretation of text and identification of legal tradition, the people were content to have justices selected primarily on the basis of legal ability. But they know that Harvard Law School, Stanford Law School - yea, even Yale Law School - do not make a man or woman any more qualified to determine whether there ought to be a right to abortion, or to homosexual conduct, or to suicide, than Joe Six-Pack. If the most significant function of the Supreme Court is thought to be the year-by-year crafting of the "Living Constitution," then what we ought to be looking for primarily is not good lawyers, but judges who agree with us, the majority, as to what the Constitution should mean. ${ }^{46}$
\end{abstract}

Scalia makes several distinct arguments. First, that the U.S. Supreme Court has been making decisions which are either blatantly contradictory to or, at best, tenuously connected with the language of the Constitution; the Court is thereby simply inventing the Constitution as it goes along. For the purpose of this discussion, I will term this the problem of unfettered progressivism. Second, Scalia argues that the original understanding of the drafters of the text is what gives life and legitimacy to the text because it is only this understanding which attained democratic primacy over all other possible understandings. Therefore this understanding must be adhered to even when several interpretations are possible on a "plain reading" of the text itself. Third, he argues that any departure from this approach is politically illegitimate. Amendment is the only proper vehicle for change because otherwise, change is done without the consent of the majority, and it is ultimately the majority that gives the Constitution and democratic society itself its legitimacy.

Professors Morton and Knopff propose what has been called a "soft Canadian variant of originalism." ${ }^{\text {"47 }}$ They reject Scalia's majoritarian rationale out of hand: "[T]he undemocratic character of judicial activism cannot be a decisive argument against it. After all, the very

" F.L. Morton \& Rainer Knopff, “Permanence and Change in a Written Constitution: The 'Living Tree' Doctrine and the Charter of Rights" (1990) I Sup. Cl. L. Rev. (2d) 533 at 539. 
purpose of rights is to limit democratic majoritarianism." ${ }^{.18}$ There is a difference between a simple democracy and a liberal democracy. In a liberal democracy, majoritarianism is tempered by liberalism or an acknowledgment of minority rights. They contend that when a right is seen as a living tree, the justification for judicial review is undermined.

In making this argument they distinguish between two types of progressive interpretation, one of which they argue is acceptable and indeed unavoidable, and the other which is not:

The first and narrower kind applies existing and well established understandings of' rights to new and unforeseen facts... When the American Supreme Court applied the riglit against unreasonable search and seizure to electronic eavesdropping in 1967, this represented a logical extension of its meaning. not the creation of a new right."

Bringing new facts under the control of existing rights does not fundamentally change the nature of the right. On the other hand:

The second and broader kind of judicial updating involves attributing such new meaning to a traditional right that it substantially changes (and evell reverses) the application of the righti....

In this context, we are concemed with the second kind of updating ... it involvis not only a much more active assertion of the judicial veto but also the assumption that entrenched rights change over time lo reflect new societal values. In this formulation. the "living tree" not only grows and changes ... but sometimes even transforms itsclf into another species, as if an oak could become a poplar."

The fundamental problem with this is that it "substitutes judicial supremacy for constitutional supremacy"sl and judges are "notoriously unrepresentative of the various sectors of society." Constitutional rights must retain some permanence. Thus, it seems fair to say that Morton and Knopff draw the line where judicial interpretation becomes judicial amendment. Another commentator, Professor Grant Huscroft, points out that "the difficulty in amending the Charter is a compelling reason for the Court to be circumspect when it comes to interpreting its provisions, since interpretation may, in effect, change the Charter." $\$ 3$ If a Court effectively changes the Charter, it would require drastic measures - an amendment - to change it back. Even if the Charter can grow and develop through interpretation, "the question is the extent to which growth and development through judicial interpretation is legitimate. ${ }^{.54}$ Both of these commentators take care to remind us that Lord Sankey, who

\footnotetext{
4s Ibid.

10 Ibid.

Thid. at 540 .

s) bid. at 546 .

52 Ibid. al 542.

33 Grant Huscroft. "A Constitutional "Work in Progress"? The Charler and the limits of Progressive Interpretation" (2004) 23 Sup. Ct. L. Rev. (2d) 413 at 417. 
invented the "Living Tree" analogy, said that the Constitution is "capable of growth and expansion within its natural limits."ss

It is fair to say that Scalia's full articulation of originalism enjoys hardly any support whatsoever in Canada. Despite this fact, there is substantial agreement with his criticism of unfettered progressivism. That is, most agree that there must be legitimate boundaries to judicial interpretation of the Constitution. Peter Hogg notes:

Originalism has never enjoyed any significant support in Canada. Indeed, as has been narrated, while Americans have debated whether the "original understanding" should be binding, Canadians have debated whether evidence of the "original understanding" should even be disclosed to the Court! 56

He also states, however, that there are limits to progressive interpretation:

Constitutional language, like the language of other texts. must be "placed in its proper linguistic. philosophical, and historical contexts." Nor is the original understanding (if it can be ascertained) irrelevant. On the contrary, the interpretation of a constitutional provision "must be anchored in the historical context of the provision." All that progressive interpretation insists is that original understanding is not binding forever. If new inventions, new conditions or new ideas will fairly fit within the constitutional language, contemporary courts ane not constrained to limit their interpretations to meanings that would have been contemplated in 1867 (or whenever the text was created). ${ }^{57}$

A form of tempered progressivism seems to be the preferred Canadian approach. In an article that is extremely critical of Scalia's originalism, Binnie J. of the Supreme Court of Canada notes that:

[Originalism] is consistent with the "contextual interpretation" often emphasized in our Chanter cases, for example, $R$. v. Big M Drug Mart Lud:

... it is important not to overshoot the actual purpose of the right or freedom in question, but to recall that the Charter was not enacted in a vacuum, and must therefore, as this Court's decision in Law Siciety of Upper Canada v. Skapinker illustrates, be placed in is proper linguistic, philosophical and historical contexts.

Moreover, our Supreme Courn has said that "Ip/urpose is a function of the intent of those who drafted and enacted the legislation at the time, and not of any shifting variable." Up to this point, the "originalists" and the "evolutionists" ane making similar noises. ${ }^{58}$

Morton \& Knopf,, stupra nole 47 at 545 [emphasis in original]: Huscrof, ibid. at 414. Hlogg. supra nole 42, vol. 2 at $57-7$ [fowtnotes omilted].

Ihid., vol. I at 15-50 [footnotes omitted], citing R. v. Big M Drug Mart, [1985] I S.C.R. 295 [Big M Drug Mart] and $R$, v. Blais. [2003] 2 S.C.R. 236, respectively.

Justice lan Binnie, "Constitutional Interpretation and Original Intent" (2004) Sup. Ct. L. Rev. (2d) 345 at 346, citing Big M Drug Mart, ibid. [footnoles omitted, emp̧hasis in original], $R$. v. Edwards Books and Art Ltd., [1986] 2 S.C.R. 713, and referring to Clurk v. Cancrion National Railway Co., [1988] 2 S.C.R. 680, respectively. 
Justice Binnie offers a cogent critique of originalism and strongly attacks Scalia's majoritarian justification:

[M]ost of the contentious provisions in the [Canadian] Constitution involve minority rights, and it seems counterintuitive to conclude that the framers of the Charter intended to leave the protection of minority rights in the hands of the legislative majorily... If the framers were content to leave these minority rights questions to Parliamentary majorities, why then they insist on enacting a Charter....?

A further survey of Binnie J.'s article reveals that he would likely agree with the following summation by Peter Hogg:

The main problem [with originalism] is that it is not possible to be confident of the "intention of the framers" or the "original understanding". This is caused by the fact that the process of constitutional amendment engaged a large number of people. Of these people, who are to count as framers? Whose original understanding or intention is important? Even if the framers could be identified, their collective intention as to points not written down in the constitutional text could not be ascertained with ectrainty ... [there is the] difficulty of attributing any particular opinion to a large group of people who did not actually vote on the point at issuc....

With respect to the Constitution Act, 1982, the proceedings of the Special Joint Committec of the Senate and the House of Commons on the Constitution of Canada indicate rather clearly that the civil servants who drafted the text and the ministers and Members of Parliament who adopted it assumed that the courts would not be bound by the views of the framers and would interpret the text in ways that could not be predicled with certainty.

These arguments are difficult to answer. A close examination of s. 24(2) of the Charfer serves only to validate that these problems with originalism are indeed serious.

\section{B. THE REJECTION OF ORIGINALISM}

The historical rejection of originalism in Canada goes back at least as far as the Privy Council's 1929 decision in Echurds v. A.-G. Can.," more commonly known as the "Persons" case. The issue before the Court was whether women were "persons" within the meaning of s. 24 of the British North America Act, $1867 . .^{62}$ and thus eligible for appointment to the Senate of Canada. The question was submitted by way of reference to the Supreme Court of Canada. ${ }^{63}$ The Supreme Court, emphasizing that the matter was one of pure statutory interpretation and not policy, held that the provisions of the B.N.A. Act, ${ }^{6+}$ must "bear

Ibid. at 377.

Hogg, supra nole 42, vol. 2 at 57-8. 57-9.

[1930] A.C. 124 (P.C.) [Edwards].

Now the Constitution act. 1867 (U.K.) 30 \& 31 Viet., c. 3, reprinted in R.S.C. 1985. App. II. No. 5 [B.N.A. Acr].

In the Matter of a Reference as to the Meaning of the Word "Persons" in Section 24 of the British North America Act. 1867, [1928] S.C.R. 276.

Sipra note 62, s. 24. 
to-day the same construction which the courts would, if then required to pass upon them, have given to them when they were first enacted. If the phrase 'qualified persons' in s. 24 includes women to-day, it has so included them in $1867 .^{\text {"ths }}$ Women were clearly not included in 1867, and therefore the Court held:

[W]omen are not cligible for appointment by the Governor (jeneral to the Senate of Canada under Stetion 24 of the British North America Act, 1867, because they are not "qualified persons" within the meaning of" that section. ${ }^{\text {th }}$

The doctrine of original intentions led clearly and directly to this conclusion.

The holding was overturned on appeal to the Privy Council. The Council clearly rejected the doctrine of original intentions in holding that women were "persons" under s. 24 of the B.N.A. Act:

Over and above that, their Lordships do not think it right to apply rigidly to Canada of to-day the devisions and the reasons therefor which commended themselves, probably rightly, 10 those who had to apply the law in diflerent circumstances, in different centuries, to countrics in different stages of development. ${ }^{67}$

The constitution was not to be interpreted with rigid adherence to the original intentions of its drafters: "The British North America Act planted in Canada a living tree capable of growth and expansion within its natural limits." It is not the duty of the court "to cut down the provisions of the Act by a narrow and technical construction" as the Supreme Court had done, "but rather to give it a large and liberal interpretation." 69

The "living tree" metaphor has been approved more recently by the Supreme Court of Canada. In Attorney General of Quebec v. Blaikic," the issue was whether s. 133 of the B.N.A. Act, which guarantees the right of any person to use either English or French in "any of the courts of Quebec"71 extends to administrative hearings. Utilizing the metaphor of the "living tree," the Court held that:

In the rudimentary state of administrative law in 1867, it is not surprising that there was no reference to noncurial adjudicative agencics.

Dealing, $a[s]$ this Court is here, with a constitutional guarantee, it would be overly-technical to ignore the modern development of non-curial adjudicative agencies which play so important a role in our socicty, and

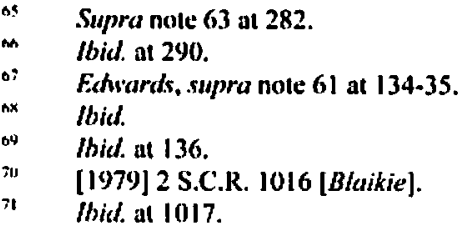


to refuse to extend to proceedings before them the guarantec of the right to use either French and English by those subject to their jurisdiction. ${ }^{2}$

As is evident from both Blaikie and Edwards, the doctrine of original intentions is often used to argue for more narrow and technical interpretations of constitutional provisions. When the Constitution is seen as a living tree, on the other hand, large, liberal, and progressive interpretation is possible.

The Supreme Court quickly made it clear that this position applied not only to the aging B.N.A. Act, but also to the Charter. As early as 1984, the Court recognized that because it is a constitutional document, the "living tree" metaphor applies to interpretation of the Charter:

The Charter is designed and adopled to guide and serve the Canadian community for a long time. Narrow and technical interpretation, if not modulated by a sense of the unknowns of the futurc, can stunt the growth of the law and hence the community it serves. ${ }^{73}$

The age of the relevant document does not seem to be the determining factor in evaluating the original intentions doctrine. Rather, originalism is philosophically incompatible with the very nature of a constitution.

Originalism is particularly inappropriate when the provision being interpreted is part of a constitutionally entrenched bill of rights, such as the Charter. A narrow and technical originalist interpretation has the effect of constricting rights and freezing development. Canadian courts are thus extremely resistant to originalism when questions of individual rights are involved, as was the case in Edwards, Blaikie, and Skapinker.

This view was strongly articulated by the Supreme Court of Canada in the B.C. Motor Vehicle Reference. ${ }^{74}$ The Court had to decide whether "fundamental justice" under s. 7 of the Charter was a merely procedural guarantee, or whether it had substantive content as well. The Court was presented with evidence of legislative history, including a large amount of testimony before the Special Joint Committee, and several witnesses including those actually responsible for drafling $\mathrm{s} .7 \mathrm{itself}$. There was unanimous agreement among these sources that s. 7 was intended to encompass procedural justice only.

Justice Lamer, for the majority, concluded that while evidence of legislative history was admissible before the Court, it was entitled to little weight. He articulates some of the dangers inherent in originalist constitutional interpretation:

Another danger with casting the interpretation of $\mathrm{s} .7$ in terms of the comments made by those heard at the Special Joint Committee Procedings is that, in so doing, the rights, freedoms and values embodied in the Charter in efrect become frozen in time to the moment of adoption with little or no possibility of growth.

73 Law Society of Upper Canada v. Skapinker, [1984] I S.C.R. 357 at 366 [Skapinker]. The question concerned the interpretation of s. 6 of the Charter.

7. Re B.C. Motor Vehicle Act, [1985] 2 S.C.R. 486 [B.C. Motor Vehicle Reference]. 
development and adjustment to changing societal needs. Obviously, in the present case, given the proximity in time of the Charter debates, such a problem is relatively minor, even though it must be noted that even at this early stage in the life of the Charter, a host ol issues and questions have been raised which were largely unforeseen at the time of such proceedings. If the newly planted "living tree" which is the Charter is to have the possibility of growth and adjustment over lime, care must be taken to ensure that historical malerials, such as the Minutes of Proceedings and Evidence of the Special Joint Commitlee, do not stunt its growth. $^{\text {ts }}$

The Court ultimately held that, contrary to the alleged intention of the drafters, s. 7 of the Charter includes substantive as well as procedural justice.

Most recently, an originalist interpretation was rejected by the Supreme Court in the Reference re Same-Sex Marriage. ${ }^{76}$ The argument was that the 1867 common law definition of "marriage" as the union of one man and one woman to the exclusion of all others was and remains entrenched in the Constitution Act, 1867. Thus, same sex-marriage is not possible without a constitutional amendment redefining the word "marriage" as it stands in the Constitution. The Court rejected this argument:

The "frozen concepts" reasoning runs contrary to one of the most fundamental principles of Canadian constilutional interpretation: that our Constitution is a living tree which, by way of progressive interpretation. accommodates and addresses the realities of modem life... A large and liberal, or progressive, interpretation ensures the continued relevance and, indeed, legitimucy of Canada's constituting document.

It was decided that the meaning of the word "marriage" as used in the Constitution Act, 1867 must not necessarily retain its 1867 meaning. Like all other terms in the Constitution, "marriage" ought to be interpreted with reference to the living tree doctrine.

There is no doubt then that the weight of judicial authority in Canada is against the original intentions doctrine of constitutional interpretation and in favour of a purposive and progressive model of interpretation. The actual merits of progressive as opposed to originalist interpretation will be dealt with more thoroughly later in this article.

\section{THE FICtIONAL INTENTION OF THE. DRAFTERS}

Every original intentions argument is necessarily premised on the assumption that there is a discernible original intention. While this assumption often remains unquestioned and unsupported, it is sometimes argued that the intention behind s. 24(2) of the Charter is a historically demonstrable fact. Thus, Paciocco claims that "[t]he whole historical development of s. 24(2) drives home the point that it was intended to be a compromise." $" 78$ However, this article outlines that careful historical review demands a different conclusion. It is a fiction to suppose that there is an actual single intention behind any section of the Constitution. It is more accurate to describe any given constitutional provision as the

25 Hbid. al 509 .

it 2004 SCC 79, [2004] 3 S.C.R. 698 [Some-Sex Marriage Reference].

"Ibid. at paras. 22-23.

is Paciocio, supra note 29 at 353. 
outcome of the tension between numerous interacting viewpoints, as part of a continual process of evolution. This "evolutionary" description is especially applicable to s. 24(2) of the Charter. The process that led to the wording of s. 24(2) was far too complicated and controversial to pinpoint any underlying spirit. Describing s. 24(2) simply as "a compromise provision," while perhaps helpful in certain contexis, is a gross oversimplification of the historical truth, and cannot be used to ground a criticism of the current jurisprudence.

Prior to the Charfer, $R$. v. Wruy ${ }^{79}$ set out the authoritative common law position on the exclusion of improperly obtained evidence. The majority of the Supreme Court of Canada overturned the Ontario Court of Appeal, and held that a trial judge has no authority to exclude evidence on the basis that its admission would bring the administration of justice into disrepute. Some discretion was recognized for a trial judge to exclude evidence in order to ensure a fair trial. This was, however, defined extremely narrowly:

It is only the allowance of evidenee gravely prejudicial to the accused. the admissibility of which is tenutus. and whose probative force in relation to the main issue belore the court is trifling. which can be said to operale unfairly.

Otherwise, all relevant evidence is admissible, regardless of how it is obtained. Three judges dissented, including Spence J., who held:

I am most strongly of the opinion that it is the duty of every judge to guard against bringing the administration of justice into disrepute. That is a duty which lies upon him constantly and that is a duty which he must always keep firmly in mind. The proper discharge of this duty is one which, in the present day of almost riotous disregard for the administration of justice. is of paramount inportance to the continued life of the state. ${ }^{\mathrm{x}}$

Even at this early stage in the recognition of civil libertics in Canada, the Ontario Court of Appeal and three justices of the Supreme Court of Canada opposed the common law's radical "inclusionary" position.

In Hogan v. The Queen," the Wray decision was applied by the majority to the Canadian Bill of Rights ${ }^{83}$ which did not contain an exclusionary provision but was completely silent on the matter. Justice Laskin, however, delivered a powerful dissenting judgment:

The Canadian Bill of Rightss ... does not embody any sanctions for the enforcement of its terms, but it must be the function of the Cours to provide them in the light of the judicial view of the impact of that enactment... There being no doubt as to such denial and violation, the Couns must apply a sanction. We would not be justified in simply ignoring the breach of a declared fundamental right or in letting it go merely with words of reprobation. Moreover, so far as denial of aceess to counsel is concemed, I see no practical

[1971] S.C.R. 272 [Wrạ]).

thid. at 293.

Ibid. at 304.

[1975] 2 S.C.R. 574 (1/ogan].

R.S.C. 1985. App. Ill [Bill of Rights]. 
alternative to a rule of exclusion if any serious view at all is to be taken, as I think it should be, of this breach of the Canadian Bill of Rights."

The ideological tension as exemplified by Laskin J. was pervasive in the days leading up to the enactment of the Charter. The Wray decision was the object of much academic criticism, ${ }^{85}$ and at least four commissioned reports recommended a revision in this area of the law of evidence. In 1969, the Canadian Committee on Corrections, chaired by Roger Ouimet, advocated for a judicial discretion to exclude illegally obtained evidence. In exercising this discretion, the courts were to take into consideration the seriousness of the breach and whether admission would be unfair to the accused. ${ }^{86}$ Likewise, the Law Reform Commission of Canada in 1975 recommended a law that "[e]vidence shall be excluded if it was obtained under such circumstances that its use in the proceedings would tend to bring the administration of justice into disrepute" with consideration given to similar factors as recommended in the Ouimet Report. ${ }^{87}$ The Ontario Law Reform Commission ${ }^{88}$ in 1976 and the McDonald Royal Commission ${ }^{89}$ in 1981 both recommended the adoption of an exclusionary rule.

It is also of interest that in the 1981 decision $R$. v. Rothman, ${ }^{90}$ Lamer J. held in dissenting reasons that there was a residual discretion to exclude otherwise admissible confessions if, having regard to the manner in which they were obtained, admission would "bring the

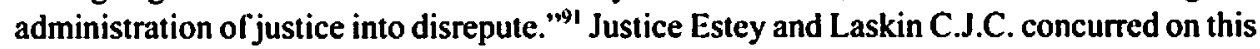
point.

There was one commission, however, that did not follow suit. The Federal/Provincial Task Force on Uniform Rules of Evidence ${ }^{92}$ essentially recommended legislation that replicated the ratio from Wray. This recommendation was set to become law by Bill S-33, the Canada Evidence Act, 1982. ${ }^{3.3}$ This task force was largely composed of members of the various governments involved. Many were Crown prosecutors, and none were members of the criminal defence bar. ${ }^{94}$

Hogan. supra note 82 at 597-98.

A. Anne Meleellan \& Bruce P. Blman, "The Enloreement of the Canadian Charter of Rights and lireedoms: An Analysis of Section 24" (1983) 21 Alta. L.. Rev. 205 at 228, n. 98.

Canaklian Committee on Corrections, Toword Unity: Criminal Sustice and Corrections (Ottawa: Queen's Printer, 1969) [Ouimet Report].

Law Reform Commission of Canada, Report on Evidence (Otawa: Information Canada, 1975) at 22. Ontario Law Reform Commission, Report on the Law of Evidence (Toronto: Ministry of the Attorney General, 1976) al 72.

Commission of Inquiry Concerning Certain Activities of the Royal Canadian Mounted Police. Freedom and Security. Under the Law. vol. 2 (Ottawa: Minister of Supply and Services Canada, 1981) at 1046-47. [1981] I S.C.R. 640.

ibid. at 698.

Uniform Law Conference of Canada, Report of the Federal/Provincial Task Force on Uniform Rules of Evidence, (Toronto: Carswell, 1982) at 174.

Bill S-33, An Act to give effect. for Canada to the Uniform Evidence Act adopted by the Uniform Law Conference of Camada, received First Reading in the Senate on 18 November 1982 and died in Second Reading.

MeLcllan \& Elman, supra note 85 at 229, n. 108. 
It is not surprising that the first version of the proposed Charter contained a very limited remedies provision, and was entirely silent on the issue of evidence exclusion. The Wray status quo would have been maintained for the time being. In a later version of the proposed Charter, there was an explicit reference to the admissibility of evidence contained in s. 26 , which would again maintain the $W$ rav principles, though it would permit contrary legislation:

No other provision of this Churler, other than section 13 [the protection against self-incrimination], affects the laws respecting admissibility of evidence in any proceeding or the authorily of Parliament or a legislature. to make laws in relation thereto."

The Federal/Provincial Taskforce recommendations, the tabling of Bill S-33, and s. 26 of the first draft of the Charter demonstrate the great deal of resistence to alter the common law's inclusionary rule in any way. The strength of this opposition to change cannot be underestimated; it went against the recommendations of four independent commissions, the arguments of numerous academics, and against the decisions of several distinguished jurists, including Chief Justice of Canada Bora Laskin. The position of the government had to have been well-considered at the very least; it can be fairly described as a deliberate refusal to implement recommended changes.

Section 26 of this proposed Charter was the subject of a great deal of debate at the Special Joim Committee on the Constitution of Canada Proceedings ${ }^{\% /}$ held in 1980 and 1981 . Civil liberties groups and others strongly opposed s. 26 and advocated for an entrenched remedy provision to prevent a repeat of the Hogan and Wray decisions. The Canadian Association of Crown Attomeys and the Canadian Association of Chiefs of Police among others advocated otherwise. The various submissions to the Special Joint Committee illustrate the profound ideological disagreement that existed at the time.

The Honourable Gordon Fairweather, Chairman of the Canadian Human Rights Commission, stated:

I have fussed and worried about the laws of evidence of this country for 15 years and it is grossly out of date and I am shocked that Section $\mathbf{2 6}$ could appear in an otherwise pretty progressive document.

This concem is with Section 26. This Section has obviously been drafted by those provincial oflicials who wish to perpetuate outmoded laws of evidence. It should be re-cast. In its present firm, it clouds all that part of the [C|harter that deals with legal rights.

The Law Retorm Commission and other professionals including scholars and practitioners will understand the genesis of Section 26 and most will share my discomfiture at seeing it as part of a [C]harler of rights and frecdoms. 97

* Canada. Senate and House of Commons, Special Join Commitfec on the Comstitution of Canada Proceedings, 32nd Parl. 1st sess., Nos. 1-57 (1980-81). 
Professor Walter Tarnopolsky, President of the Canadian Civil Liberties Association, delivered an impassioned plea to the Special Joint Committee:

Ordinarily one would expect that when a bill of rights sets out certain rights and freedoms, that a remedy would be presumed. In other words, our cours would not be moved to assert there is a right unless there is a remedy, but if I could take you back briefly to the Supreme Court decision in the Hogan case, you will know that the majority of our Supreme Court has not followed that kind of logical conclusion.

[W]hat the Supreme Court then said was that they could not find in the Canadian Bill of Rights a reason to override the long standing rule of evidence, that evidence if obtained even illegally is admissible if relevant. Now, that, Mr. Chairman, we suggest is exactly what section 26 enshrines.... 1 cannot inagine a Bill of Rights that we would want to hold up proudly in the world having that kind of a provision specifically prolected. ${ }^{9 \times}$

This position was supported by others, including Professor Joseph Magnet, Special Advisor for the Canadian Jewish Congress, who stated before the Committee:

[T]he Hogan case in the Supreme Court, it recognized the violation of legal rights under the Diefenbaker Bill of Rights, the coun said: Well, we see no remedies elause here, we cannot grant a remedy.

[W] think that to deal with problems like this, as well as the full panoply of rights which will be entrenched in the [C] harter, that an enforcement clause is crucial, that the [C]hanter would be hollow without it. ${ }^{49}$

The National Association of Women and the Law presented similarly strong sentiments:

Section 26 as it reads now denies the application of the Charter to laws of evidence... We note that this section was apparently included to avoid the introduction of the poisoned fnit doctrine, i.e. that illegally obtained evidence cannot be introduced in court against an accused.

First of all, we question whether the present law as it stands, that stech evidence can be introdluced, should be allowed to stand. It is ablorrent that the law enforeement agencies do not have certain checks on them to prevent them from gathering evidence illegally. ${ }^{100}$

These views were strongly opposed by the Canadian Association of Crown Counsels and the Canadian Association of Chiefs of Police. Chief John Ackroyd of the Metro Toronto Police appeared before the Committee to make submissions:

The Association agrees with [s. 26] as now written and would be strongly opposed to any change. 
It is the understanding of the Canadian Association of Chiefs of Police that the Canadian Civil Liberties Associution has recommended, in effect, to the Committec that it adopt the United States Exclusionary Rulc. commonly known as the "Fruit of" the Poisoned Tree."

In the United States, this nule has proven to be the greatest single road block to effective and fair law enforcement.

When murderers are set free because a police officer has made a minor mistake in the procedures he is required to follow, does socicty really benefit? ${ }^{101}$

The Police Association also took a strong general position against entrenching a bill of rights in the Constitution at all.

The following argument was made by Mr. Robinson, MP for Bumaby, British Columbia:

How would you feel about a nile which would say that in certain circumstances that our court should have a discretion to exelude evidence which has been obtained in a way that would bring the administration of justice into disrepute. Not that there should be an automatic exclusion, but that the courts should at least have a discretion to look at the way that cvidence has been obtained. ${ }^{102}$

Mr. Roderick McLeod, Assistant Deputy Attomey General of Ontario made submissions on behalf of the Crown Counsels Association, and responded to Mr. Robinson's submission: "[i]t is our submission that the court ought not to have that kind of discretion, because of the very reasons that were examined ... in the Wray case not too long ago in this country, where that very issue was the subject of considerable debate."103

After much negotiation, and submissions from the New Democratic Party and Progressive Conservative Party of Canada, the present text of s. 24(2) was adopted. ${ }^{104}$

Speaking to the meaning of the final version of the exclusionary remedy section, now s. 24(2), Don Stuart asserts:

That the government draflers intended exclusion to be rare is crystal clear from the following exchange during the Committec procecedings:

Senator Austin: Mr. Chairman, one question of Mr. Ewaschuk, could you provide the commitlec with the general definition of the test "bring the administration of justice into disrepute?". Is there a general principle that you could articulate that would give us a dividing line? 
Mr. Ewaschuk: (Q.C., Director Criminal Law Amendment Section. Department of Justice) Well, somebody told me today - I am on a task lore to revise rules of evidence - and Dr. Tollefson from the Federal Department of Justice is the head of it and he says the lest is as articulated by the former Justice Black of the United States, that the admission of this evidence would make me vomil, it was obtained in such a reprehensible manner. I said to Dr. Tollefson, it might be a little tough writing that in. but that is the type of case, he is saying, where the conduct is very blameworthy, repugnant, very reprehensible, what the police did in the circumstances and therefore although, and this is the other argument, they had been lawbreakers allow another lawbreaker. an aceused, to go free. Once it has reached this certain level of reprehensibility, it should be excluded. ${ }^{105}$

This statement must be seen in its historical context. The government had a demonstrated record of opposing change to the common law inclusionary rule. It is not surprising therefore, that after a change was made to the draft Charter because of outside pressure, the government hoped that the exclusionary remedy would be rarely used. This can hardly be described as an underlying "intention" behind the section. Interestingly, Ewaschuk J., whom Stuart quotes as the authoritative government voice, is currently a justice of the Ontario Superior Court of Justice. and was recently asked by the defence counsel in a murder case to recuse himself because of his reputation in the community for being biased in favour of the Crown. ${ }^{106}$ Regardless, it is evident from the historical record as presented that the current s. 24(2) was the product of a great amount of tension, the expression of numerous voices. It is clear that the government was reluctant, to say the least, to accept anything other than the Wray regime for exclusion, and had to be virtually bullied into proposing s. 24(2). Section $24(2)$ is best described as an acknowledgment that the Charter should contain a remedy when evidence is obtained in violation of guaranteed rights. The courts are given the power to exclude evidence when its admission would bring the administration of justice into disrepute. The meaning of this vague phrase was deliberately left to the courts to develop in the jurisprudence.

It cannot be legitimately argued that s. 24(2) was the expression of any single intention. No discernible legal doctrine can be derived from the controversy leading up to the proposal and enactment of the section. The comments of Lamer J. in the B.C. Motor Vehicle Reference are especially apposite:

[The simple fact remains that the Churler is not the product of a few individual public servants, however distinguished, but of a multiplicity of individuals who played major roles in the negotiating. drafting and adoption of the Charter. Ilow can one say with any confidence that within this enormous multiplicity of actors, without forgetting the role al the provinees, the comments of a few federal civil servants can in any way be determinative?

Itu Kirk Makin, "Ontario judge, lawyer trade recusal barbs; Defence allempts to remove jurist, saying 'reputation for unfaimess is well known'" The Globe and Mail (2 March 2005) A8. It is not being suggested that the application latal any merit, but is merely being put forwand as anecdotal evidence: someone with this ideological reputation (regardless of how ill-founded it may be) is now potentially seen as forming the "original intention" behind s. 24(2) of the Charter. 
Were this Court to accord any significant weight to this testimony, it would in effect be assuming a fact which is nearly impossible of proof, i.e., the intention of the legislative bodies which adopled the Charter. In view of the indeterminate nature of the data, it would in my view be erroneous to give these materials anything but minimal weight. ${ }^{107}$

Even if the original intentions doctrine is presumed to be valid and is applied, no meaningful original intention can be seen to be behind s. 24(2). The cardinal problem with originalism, "is that it is not possible to be confident of the 'intention of the framers' or the 'original understanding'. This is caused by the fact that the process of constitutional amendment engaged a large number of people. Of these people, who are to count as framers? Whose original understanding or intention is important?"108 These observations most certainly apply to s. 24(2) of the Charter. With this insight, it cannot be honestly maintained that there is a discernible intention behind s. 24(2) capable of grounding a criticism of the now highly developed Stillman rule for the general exclusion of non-discoverable conscripted evidence.

\section{Progressive vs. Frozen INTERPRetations of Charter Riguts}

The original intentions doctrine is most often used to support narrow and technical interpretations of constitutional provisions based on the fiction that there is a clear intention behind the provision in question. Even if it is assumed for the sake of argument that there is a discernible original understanding, there is still no good reason why a court should consider itself bound by that understanding. The original intentions doctrine has the effect of inhibiting the healthy development of law by freezing into the Constitution a particular interpretation that is not mandated by its clear language. Thus, the Supreme Court has held that the interpretation of the Charter should be progressive and purposive, not originalist. This same doctrine ought to apply to the interpretation of s. 24(2). In upholding the exclusionary rule for conscriptive evidence, the majority in Stillman is faithful to these interpretive principles.

A progressive interpretation allows the language of the Constitution to be continuously adapting to new conditions and ideas. The Supreme Court set this out in Hunter v. Southam, an early Charter case interpreting the s. 8 phrase "unreasonable scarch and seizure":

A constitution ... is drafted with an eye to the future. Its function is to provide a continuing framework for the legitimate exercise of governmental power and, when joined by a Bill or a Charter of Rights, for the unremitting protection of individual rights and liberties. Once enacted, its provisions cannot easily be repealed or amended. It must, therefore, be capable of growth and development over time to meet new social, political and historical realities often unimagined by its framers. The judiciary is the guardian of the constitution and must, in interpreting its provisions, bear these considerations in mind. ${ }^{109}$

Hogg points out that, in fact, such an interpretation was the intention of the framers. 
What originalism ignores is the possibility that the framers were content to leave the detailed application of the Constitution to the courts of the future, and were content that the process of adjudication would apply the text in ways unanticipated at the time of drafting. ${ }^{110}$

Thus, the language of a constitution is often couched in general terms so as to enable suitable interpretation by the courts, so that the values are adaptable to new ideas and circumstances. This is perhaps why the claim of unfaithfulness to original intentions is linked with the claim that a particular interpretation is not consistent with the plain meaning of the actual language used." The language of s. 24(2) is sufficiently vague to permit a number of possible legitimate interpretations. Given the ambiguity of the language in s. 24(2), the Court should and did in fact look at s. 24(2) with a progressive eye.

This is the crux of the intense dialogue between Sopinka J. and L'Heureux-Dube J. in Burlingham. Justice Sopinka iterates the rationale behind the exclusionary rule for conscriptive evidence, noting that L'Heureux-Dubé J. "does not criticize the principle that the admission of evidence that would render the trial unfair would bring the administration of justice into disrepute" but rather that it is only unreliable evidence that can render a trial unfair and thus be automatically excluded. ${ }^{112} \mathrm{Her}$ approach appears "to be a close relative of the rule in R. v. Wray,"113 a remark to which L'Heureux-Dubé J. look great exception. ${ }^{1 / 4}$ Justice Sopinka describes s. 24(2) jurisprudence as being in the process of "incremental evolution." $1 / 5$ While remaining faithful to Collins, the Court must strike "the appropriate balance between a restrictive versus a liberal exclusionary rule" and remain "faithful to the values that the Charter protects." 16

\section{E. TuE Necessity of a Progressive Interpretation of Section 24(2)}

The process of recognizing civil liberties and legal rights in Canada was slow and arduous. Thirty years ago judges could be heard making statements such as, "even if he had been knocked down and beaten and the blood sample extracted from him, it would be admissible... There is not the slightest doubt in my mind on that," 117 and, "the fact that a statement was beaten out of a witness is irrelevant. The question, is whether or not that statement is true." 118

The existence of a constitutionally entrenched provision for the exclusion of illegally obtained evidence was one step among many in the right direction. By 1994, the majority of the Supreme Court of Canada would say:

"Hogg, supra note 42, vo. 2 at 57-8 [footnotes omited].

III This is the claim made by McLachlin J., dissenting in Stillman, supra note 2 at paras. 2391r.

112 Burlinghom, supra note 5 at para. 146.

11. Thid. at para. 147, Sopinka J.

II4 Kid. al para. 107.

11. Kid. at para. 154.

116 Ibid. per Sopinka J.

I7 R. v. Devison (1974), 10 N.S.R. (2d) 482 at 489 (C.A.), Macdonald J.A. quoting the trial judge.

IIR R. v. Paquette (1975), 27 C.C.C. (2d) 145 at 148 (Ont. Prov. Ct.). 
[W]e should never lose sight of the fact that even a person accused of the most heinous crimes, and no matter the likelihood that he or she actually committed those crimes, is entitled to the full protection of the Charter. Short-cutting or short-circuiting those rights affects not only the accused, but also the entire reputation of the criminal justice system. It must be emphasized that the goals of preserving the integrity of the criminal justice system as well as promoting the decency of investigatory techniques are of fundamental importance in applying s. 24(2). ${ }^{119}$

The language of $s .24(2)$ is best seen as a general expression of a liberal principle which gained gradual recognition in Canada, a principle which must continue to evolve with new circumstances and ideas. Criticism which relies merely on the notion of an original intention must, therefore, necessarily fail.

The virtue of a progressive doctrine of constitutional interpretation is that, though the language of a constitution is for all intents and purposes permanent, the meaning attributed to the language, the judicial interpretation, remains flexible and able to adapt to accommodate new circumstances and new ideas. This feature of progressivism is particularly important with respect to the interpretation of s. 24(2). Since the advent of the Charter in 1982, judges, lawyers, academics, and the Canadian public have developed a greater knowledge and awareness of police investigatory techniques and the importance of the practical functioning of the criminal justice system. This is in itself a justification for a progressive interpretation of s. 24(2).

A major reason for this increase in knowledge and awareness is the very fact that Canada now has a constitutionally entrenched bill of rights. Prior to the Charter, many aspects of police investigation remained private as they were simply not relevant to trial court proceedings. The introduction of mandatory Crown disclosure by the Supreme Court in $R$. v. Stinchcombe ${ }^{121}$ opened the doors to a myriad of possible issues for litigation in even the most typical criminal trial. In addition, the very existence of the right to counsel under $s$. 10(b), protection from unreasonable search and seizure and arbitrary detention under ss. 8 and 9, and equality under $\mathrm{s} .15$ of the Charter permitted the litigation of issues which were never-proven but long-suspected problems. The very nature of the s. 24(2) inquiry necessitates a deep look at investigatory techniques and the pre-trial process. Thus, the advent of the Charter in Canadian law has caused much change in the criminal trial process. The practical impact that the Charter has had on the criminal process has not been ignored. Justice Marc Rosenberg of the Ontario Court of Appeal notes that, "[i]t was perhaps inevitable that the Charter of Rights would place a heavy burden upon the criminal courts. The day to day business of the trial and appellate courts has shifted from the determination of guilt or innocence to the business of applying the Constitution." 21 There can be no doubt that the Charter has constitutionalized the criminal investigative process. It is recognized as a principle of law in Canada that the state cannot override the rights of its citizens in order

114 Burlinghum, supra note $S$ at para. 50, lacobucci J.

13) [1991] 3 S.C.R. 326. Anything in possession of the Crown that is not clearly irtelevant or privileged must be diselosed to the defence counsel.

13. The Honourable Mare Rosenberg, "The Impact of the Charter on the Law of Evidence in Criminal Cases" in Jamie Cameron, ed., The Charter's Impact on the Criminal Justice System (Scarborough: Carswell, 1996) 181 at 184. 
to perform criminal investigations and secure convictions. The ends in such situations do not, as a matter of principle at least, justify the means.

Commentators differ drastically in their evaluation of the impact of the Charter, but none doubt that there has indeed been an impact. Alan Young explains that there are two basic schools of thought when it comes to the criminal process, and two corresponding views of the Charter: "For some, the Charter has secured fair process and has trimmed the process of some of its worst excesses, while for others, the Charter has done nothing more than handcuff police forces who are already overburdened by a burgeoning crime rate and significant legal restrictions on their powers."122

Herbert L. Packer has eloquently described the two schools of thought as "crime control" and "due process" and has crafted corresponding metaphors for each. For the crime control advocate, stopping crime is the foremost goal of the criminal justice system, and as such, the fewer restrictions placed on the police, the better. Its metaphor is the assembly line:

There must be a premium on speed and finality. Speed, in turn, depends on informality and on uniformity: finality depends on minimizing the occasions for challenge. The process must not be cluttered up with ceremonious rituals that do not advance the progress of the cuse. Facts can be established more quickly through interrogation in a police station than through the formal process of examination and crossexamination in coun. ${ }^{123}$

The metaphor for "due process," on the other hand, is the obstacle course. Individual rights are emphasized, and abuses of state power are not to be tolerated. The underlying values "can be expressed in, although not adequately described by, the concept of the primacy of the individual and the complementary concept of limitation on oflicial power." ${ }^{\text {"124 }}$

It is submitted that the inauguration of the Canadian Charser represented a long needed recognition of due process and individual rights. The majority approach in and subsequent to Stillman is an accurate reflection of these Charter values. It is a clearly articulated and thoughtful response to the predominating "crime-control" mentality. Hence Sopinka J. and lacobucci J. make statements upholding the rights of all, even those accused of the most heinous crimes. Justice L'Heureux-Dubé, on the other hand, argues that more serious violations of rights are justifiable when a person is accused of more serious crimes. For her, faimess means reliability, which is paramount. For the majority, fairness means a respect for individual rights, and this is the paramount consideration.

If the Charter is a milestone in the recognition of individual rights, and if those rights are to be taken seriously, then the crime control mentality is no longer tenable. This is not being submitted merely as a matter of philosophy, but as a matter of practice. Such a view cannot be honestly maintained in the light of current knowledge of the criminal process. There has

Alan N. Young. "The Charter, the Supreme Court of Canada and the Constitutionalization of the Investigative Process" in Cameron, ibid. 1 at 1. 
been recent judicial recognition of the existence of racial profiling ${ }^{12 s}$ and the existence of systemic investigation problems. ${ }^{126}$ The role of police in wronglul convictions has been recognized in numerous public inquiries. ${ }^{127}$ This area of the law, like all others, is continually evolving, and this process should not be inhibited. Seen in this light, originalism is a particularly inappropriate doctrine to apply when attempting to interpret s. 24(2). Canadian law should not recognize a "frozen-rights" approach in its criminal law. The implications of such a doctrine are enormous. Accordingly, such an approach is universally regarded as unacceptable in every other field of human rights law. There is no reason why the same standards should not be applied when interpreting s. 24(2).

\section{OPENING THE BACK DOOR TO CONSCRIPTIVE EvIDENCE: ORBANSKI AND GRANT}

The numerous concerns articulated in this article have come to light in the recent $O r h a n s k i$ decision of the Supreme Court of Canada. The reasons of LeBel J. in this case are curious. Despite the fact that the evidence in question was properly admissible even on a narrow reading of settled jurisprudence, he admits the evidence on a much wider basis by establishing an essentially new test for the admission of conscriptive evidence without addressing any of the underlying policy concerns. These reasons have been adopted by Laskin J.A. of the Court of Appeal for Ontario in the case of $R$. v. Grant ${ }^{128}$ and the analysis has been approved by Rosenberg J.A. in the case of $R . v$. Lolozk $y^{\prime 2 "}$ thus demonstrating their potential sphere of influence.

\section{A. The "Plain Meaning" of Section 24(2)?}

Both Laskin J.A. in Grant and LeBel J. in Orbanski dismiss the Stillman test as being clearly inconsistent with the "plain meaning" and the "structure and the wording" of s. 24(2). Section 24(2), they say, demands a consideration of all the circumstances of the case. An automatic exclusionary rule contradicts this language. This argument is not new and, in fact, was proposed in the dissenting judgments in both Burlingham and Stillman. It was not adopted by the majority of the court in both cases and was thus de facto rejected. In Burlingham, L'Heureux-Dube J. argued that, "it runs counter to the inherently discretionary nature of a s. 24(2) determination, which is to be made having regard to all of the circumstances', to formulate rigid rules or presumptions for the exclusion or admission of different kinds of evidence."1310 Justice McLachlin criticized the Stillmem majority's interpretation in a similar manner: "The approach that l suggest, as opposed to the majority's approach, preserves the consideration of 'all the circumstances' and the balancing of factors

\footnotetext{
i2s Sce R. v. S.(R.J.). [1997] 3 S.C.R. 484; R. v: Brom (2003), 64 O.R. (3d) 16] (C.A.).

1:6 See R. v. Calderom (2004). I88 C.C.C.(3d) 481 (Ont. C.A.); R. v. (7a!rm (2005), 194 C.C.C. (3d) 280 (Ont. C.A.).

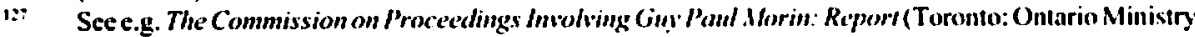
of the Attumey General, 1998).

188 (2006), 81 O.R. (3d) I (C.A.) [Gram].

Iz9 (2006), 81 O.R. (3d) 335 (C.A.). A similar test is set out as in Crrm but it is obirer dicta.

130 Burlingham, supra note 5 at para. 89.
} 
for and against admission required by s. 24(2). It avoids the automatic exclusionary rule eschewed by the framers of the Charter."131

The "plain meaning" argument in this context is a clear red-herring. It is trite that "all the circumstances of the case" should be considered when deciding whether to exclude evidence. The majority in Stillman simply articulated a forceful argument that in certain circumstances it is nearly always the case that evidence ought to be excluded - circumstances where the evidence is conscriptive. This proposition is supported by the following argument:

Conscriptive evidence that is not discoverable affects the fairness of the trial;

Anything that affects the fairness of the trial must necessarily bring the administration of justice into disrepute; and

Anything that brings the administration of justice into disrepute must be excluded under s. 24(2).

Since this argument is valid and has been proposed (at least implicitly) by the majority of the Supreme Court, it would seem that the onus lies on the dissenter to answer the argument by establishing that at least one of the three premises are false. Both Laskin J.A. and LeBel J. have simply rejected this argument out of hand, without providing any supporting reasons whatsoever. The "plain meaning" argument simply by-passes the majority's argument in Stillman - it does not argue that any one of the three premises outlined above are false. ${ }^{132}$ This can be established by examining the premises.

The first statement clearly has nothing to do with the language of the section - it is a statement of fact which may or may not be true. Since the plain meaning argument is not addressing the issue of whether or not this is true, that would be a policy question, but only addressing the language itself, the argument does not attack this statement. The third statement is identical to the language of the section and so cannot be attacked. The plain meaning attack must thus pertain to the second premise. But the second premise is simply another way of saying that there are certain "circumstances" which always bring the administration of justice into disrepute, namely an unfair trial. Thus, even if all the other circumstances are evaluated, it could not change the fact that an unfair trial brings the administration of justice into disrepute. This is fatal, and cannot be alleviated. It does not seem, then, that the majority approach is on its face incompatible with a plain reading of the section. Indeed, the section is capable of many interpretations given its vague language: McLachlin C.J.C, Cory, LeBel JJ., and Laskin J.A. all have potentially valid interpretations on a "plain reading" of the language of the section. Thus a full interpretation of s. 24(2) must go beyond the basic "plain meaning" of the language, and must determine which of all the possible interpretations is best. This is ultimately a policy decision. In Stillman, the Court

Both McLachlin and L'Heureux-Dubc JJ. dispute at least the first premise of this argument, in their decisions in Burlingham and Stillman respectively, on the grounds that the self-incriminatory nature of conscriptive evidence does not necessarily affect trial faimess in the degree contemplated by the majority in Stilman. Justices Laskin and LeBel do not even address the underlying argument. 
engaged in such a serious policy debate and considered the numerous previous decisions, academic criticism, and the input of numerous interveners. A decision was reached and the rationale was clearly articulated. Presently, the common law principle of stare decisis applies to the majority reasons in Stillman and the onus lies on those who wish to change or develop the law to clearly articulate the reasons behind any change. This has not been done in either Orbanski or Grant.

\section{B. ORBANSKI: THE FACTS}

The main issue in Orbanski is the scope of the admissibility of non-discoverable conscriptive evidence. The Supreme Court in Stillman stated unequivocally that where evidence is classified as conscriptive and is not otherwise discoverable, it adversely affects the fairness of the trial and must for this reason be excluded. This automatic exclusionary rule is subject only to a rare exception: where the evidence was obtained through a minor or technical Charter breach, it might not affect trial faimess and thus would not be automatically excluded.

An RCMP officer observed Mr. Orbanski proceed through a stop sign without stopping and then swerve on the road. The officer stopped him, approached the car, observed that his eyes were glassy and detected the odour of alcohol on his breath. When asked, Orbanski informed the officer that he had consumed one beer that night. He was then asked to step out of the vehicle and perform some sobriety tests. He was told that the tests were voluntary and that he could contact a lawyer immediately on a cell phone, but was not informed of the availability of duty counsel. He declined to contact the lawyer, and performed the tests which consisted of reciting the alphabet, walking in a straight line heel to toe while counting to ten, and looking at the officer's finger while the officer moved it in front of him. Being unable to perform the tests, he was arrested for impaired driving. He was then transported to the police station, fully advised of his rights to counsel, and was required to provide breath samples. It was determined that his blood alcohol readings exceeded the legal limit and Orbanski was also charged with driving "over 80."133

The majority of the Supreme Court determined that Orbanski was detained at the side of the road when he was stopped by the RCMP thus triggering s. $10(b)$ of the Charter. However, the request to perform sobriety tests and the questions about alcohol consumption were found to be reasonable limits within the definition of $s$. 1 . Thus, the appellant's Charter rights were not violated and no s. 24(2) analysis was necessary. The results of the sobriety tests were admissible, which provided the reasonable and probable grounds for the breath samples, which were therefore validly obtained and also admissible.

11 Orbomski, suma note 4 at paras. 5-8. Omanski and Efias were two very similar calses issued as (wwin judgments by the Supreme Court of (anuda. The facts in Flicas will not be recounced becausc s. 24(2) was not at issue. The majority did not need to analyee s. 24(2) because they found no (heurter violation. The dissent, which found a Chorter violation, was bound by the Manitoba Coun of Appeal's decision excluding the evidence under s. 24(2), because lilias was denied leave to cross-appeal that issue. It is a strong inference that L.eBel and Fish JJ. would have also adruitled the evidence against Elias under $\mathbf{S}$. 24(2) had leave been granted. This then would also have been a concurring judgment. As it stands, their judgment on Elias is in dissent: their judgment in Orbanshi is concurring. 


\section{THE ADMISSIBILITY OF THE EVIDENCE}

Justices LeBel and Fish issued a concurring judgment on the matter of Orbanski. They found that even though the police conduct was a violation of s. 10(b) which was not justified under s. 1, the evidence obtained was admissible under s. 24(2). The s. 24(2) analysis is interesting to say the least. However the reasons of LeBel J. are brief. The issue of exclusion will therefore be examined in greater depth. It will be argued that even according to a narrow reading of Cory J.'s own reasons in Sillman, the evidence in Orhanski is admissible. Justice LeBel however admits the evidence based on a much wider and unnecessary reinterpretation of s. 24(2).

The evidence in question is the results of the sobriety tests, the statement to police regarding alcohol consumption, and the subsequently obtained breath sample. The sobriety tests and statement were illegally obtained in violation of s. 10(b): Orbanski was detained and not advised of his right to contact duty counsel as required. ${ }^{134}$ Since these formed the grounds for a breathalyzer demand, the demand was made without a legal basis and the breath sample therefore was also illegally obtained. This remains true despite the fact that Orbanski was properly informed of his rights to counsel before the breath demand was made. All the evidence was therefore illegally obtained; therefore, it is all subject to s. 24(2) analysis.

Several facts should be noted, as they to militate in favour of inclusion:

- Orbanski was immediately informed of his right to contact counsel (just not duty counsel) and was offered a cell phone to do so. He understood and declined this opportunity.

- Orbanski understood that it was his choice to do the sobriety tests and did them voluntarily.

- Orbanski was fully and properly informed of his rights to counsel once the officer formed grounds to demand a breath sample.

Consequently the entire Charter breach hinges on the fact that Orbanski was not informed of his right to contact a free lawyer prior to undertaking to do what he knew to be a voluntary sobriety test.

As a general rule, conscriptive evidence affects trial faimess. The right against selfincrimination is a fundamental tenet of a fair trial. When an accused is conscripted into giving evidence against himself, his right against self-incrimination is infringed, and that essential element of a fair trial is violated.

134 R. v. Brydges, [1990] I S.C.R. 190. A point conceded by the Crown. This statement is accurding to LeBel and Fish JJ. According to the majority, there was no Charter violation and the samples were not illegal al all. 
It is becouse the accused is compelled as a result of a Charfer breach to participate in the crealion or discovery of self-ineriminating evidence in the form of confessions, statements or the provision of bodily samples, that the admission of that evidence would generally tend to render the trial unlair. ${ }^{135}$

However, it is established law that this general rule, "like all rules, may be subject to rare exceptions." ${ }^{136}$ There are procedures that are so unintrusive and routinely performed that they are accepted without question by society and "[s]uch procedures may come within the rare exception for merely technical or minimal violations referred to earlier." 137 Two examples are given: fingerprinting and breath samples. In the rare case where the conscriptive evidence does not affect trial faimess due to the minor nature of the infringement, the court is to go on to consider the second and third Collins factors.

Conscriptive evidence that is not otherwise discoverable is excluded as a general nule. The only exception to this rule is where the admission of the evidence does not affect trial fairness due to the minor or technical nature of the breach. It is to be emphasized that the exception only arises where trial fairness is not impacted. When conscriptive evidence affects trial faimess, as it usually will, there is no exception, and the evidence is automatically excluded.

The possible existence of exceptional circumstances was reaffirmed in $R$. v. Feeney. ${ }^{13 \mathrm{x}}$ In obiter, Sopinka J. argued that fingerprints obtained in the context of incident to an unlawful arrest are conscriptive evidence obtained in violation of s. 8 of the Charter: "Where, however, the arrest is unlawful by reason of a technicality, the product of the search may be admissible under s. 24(2) of the Charter." ${ }^{139}$ And later in the decision, Sopinka J. held that statements provided to the police were obtained in violation of s. 10(b): "The admission of the statements therefore would affect the fairness of the trial. Given that no exceptional circumstances exist in this case, the admission of the conscriptive, non-discoverable statements would render the trial unfair; thus the statements are inadmissible under $s$. 24(2)."140 While the statements were ruled inadmissible, there exists a distinct possibility that exceptional circumstances can render conscriptive evidence admissible.

Such exceptional circumstances have been found in several cases. In R. v. Tremblay, ${ }^{1+1}$ the constitutional violation was related to the accused's own unreasonable and obnoxious behaviour, and the accused actively obstructed the investigation. The illegal breath sample was therefore admitted. In $R, v . M o h l l^{1.2}$ the accused was so intoxicated that he was unable to understand his right to counsel. The state of intoxication is a self-imposed impediment, and was an element of the offence of driving "over 80." A unanimous Supreme Court agreed, without substantial reasons, that the breath evidence was admissible under s. 24(2). In $R$. v.

Stillman, supra note 2 at para. 73 [emphasis in original].

Jbid.

lbid. at para. 90.

[1997] 2 S.C.K. 13 [Feeney].

lbid. al para. 60.

Ibid. at para. 65.

[1987] 2 S.C.R. 435.

[1989] I S.C.R. 1389. 
Dewald, ${ }^{143}$ a breath sample was obtained illegally; however, the breach was technical and the officer acted in good faith. Justice Sopinka held that the admission of the evidence did not render the trial unfair and was therefore admitted. In $R$. v. Richfield, ${ }^{144}$ the Ontario Court of Appeal noted in an obiter discussion that there is authority that breath samples (and other conscriptive evidence) obtained through a minor breach of Charter rights may constitute an exception to the automatic exclusionary rule for conscriptive evidence, and suggested that trial judges apply all three Collins factors in such scenarios. Finally, in $R . v . V u,{ }^{145}$ the British Columbia Court of Appeal noted, again in an obiter discussion, that there is no absolute prohibition on admitting conscriptive evidence. Thus, when a police officer trespasses to knock on someone's door with the sole intention of ascertaining their identity, even if there is a s. 8 Charter violation and the evidence is classified as conscriptive, the breach constitutes such a minimal interference with privacy that that the evidence ought to be admitted.

There is ample authority that non-discoverable conscriptive evidence is nevertheless admissible under s. 24(2) if the Charter breach is technical or minor. Trial fairness is not affected in such circumstances, and subject to the other two Collins factors, its admission would not bring the administration of justice into disrepute. This situation is rare, and is an exceptional circumstance.

The evidence in Orbanski, though conscriptive, is arguably admissible on this basis. The breach was technical and was quickly corrected. The initial violation which triggered the breach was very minor, and was not a significant invasion of privacy or bodily integrity. Orbanski acted voluntarily, there was no significant cocrcion, and the officer acted in good faith. As Cory J. stated in Stillman:

[A] particular procedure may be so unintrusive and so routinely performed that it is accepted without question by society. Such procedures may come under the rare exception for merely technical or minimal violations referred to earlier.... Similarly, the Criminal Code provisions pertaining to breath samples are both minimally intrusive and essential to control the tragic chaos caused by drinking and driving. ${ }^{\text {th }}$

The results of the sobriety tests and breath sample in Orbanski are a rare example of admissible conscriptive evidence. This is acknowledged by LeBel J. in his reasons. However, he overstates the case for admission, reasoning more widely than is necessary in the circumstances. This combined with various other comments mark a departure from existing s. 24(2) jurisprudence.

Justice LeBel begins by commenting that all the academic and jurisprudential commotion that has arisen surrounding s. 24(2) is a result of an "attempt to read into the jurisprudence of our Court the creation of an exclusionary rule in the case of conscriptive evidence." ${ }^{.17} \mathrm{He}$ says, later, "[n]either the reasons of Cory J. in Stillman nor a number of recent

[1996] I S.C.R. 68.

(2003), 178 C.C.C. (3d) 23 at paras. $14-18$ (Ont. C.A.), Weiler J.A. with $0^{\circ}$ Connor A.C.J.O. and Abella J.A. also on the panel [Richlfield]. 1999 BCCA 722, [1999] 133 B.C.A.C. 158.

Srillman, supra note 2 at para. 90.

Orbanski, supra note 4 at para. 87. 
pronouncements of our Court ... have gone that far." ${ }^{\text {14k }}$ Considerable importance is attached to the nature of the evidence, and there is constant concern that conscriptive evidence obtained in breach of a Charter right may affect trial fairness. "Nevertheless, while this part of the analysis is often determinative of the outcome, our Court has not suggested that the presence of conscriptive evidence that has been obtained illegally is always the end of the matter and that the other stages and factors of the process become irrelevant."149

Justice LeBel cites three cases in support of this interpretation: $R . v . B u h a y,{ }^{150} R . v$. Fliss, ${ }^{151}$ and $R$. v. Law. ${ }^{152}$ In each, he argues, the Court reasoned that a s. 24(2) inquiry involving conscriptive evidence remains a comprehensive intellectual process, which involves the delicate and nuanced balancing of interests. Although exclusion often occurs at the end of the process, all the Collins factors remain relevant, and " $[\mathrm{t}]$ he inquiry into the admissibility of the evidence must reach the last stage so that it can be determined whether the admission of the evidence would bring the administration of justice into disrepute."153

The use of this authority to support this proposition is problematic. None of the cases involve conscriptive evidence, and the Court did not attempt a detailed analysis of the issue. The comments cited involving a delicate, nuanced, and balanced inquiry are simply quoted out of context. The suggestion was never made that if evidence is classified as conscriptive, a court must go on to consider the other branches of the Collins test. Justice LeBel, on the other hand, holds:

The creation and application of a rule, based on a presumption that conseriptive evidence necessarily affects the fairness of a trial, of almost automatic exclusion whenever such evidenee is involved might be viewed as a clear and elfective method to manage aspects of a criminal trial. Nevertheless, our Court has never adopled such a rule, which could not be reconciled with the structure and wording of $\$ .24(2){ }^{154}$

Indeed, it "may be impossible to divorce the different stages of analysis, given the logical and factual interplay between them in many cases." 155 These statements cannot be reconciled with the doctrine as outlined in Stilman, where the opposite was clearly stated.

To summarize LeBel J.'s understanding of s. 24(2) analysis:

- It is a delicate and nuanced inquiry involving the balancing of competing interests.

- The classification of evidence as conscriptive is important, and the court must remain mindful of the impact such evidence has on trial faimess. 
- This is not, however, determinative. The threc branches of the Collins test are intertwined, and so a court must go on to consider the seriousness of the breach and the effect on the repute of the administration of justice even when the evidence is classified as conscriptive.

There is no recognition of the general rule that conscriptive non-discoverable evidence affects trial fairness and is to be excluded without further consideration of the seriousness of the breach or the effect on the repute of the administration of justice. This rule is subject only to rare exceptions, where the breach is minor or technical, and only then will the court go on to consider the other two Collins branches. Justice LeBel claims to be simply restating well-established principles; however, he does not grapple with the test as articulated in Stillman.

Justice LeBel could have admitted the evidence under the "technical breach" exception to the conscriptive evidence rule as articulated in Sillman. Instead, he chose to articulate an essentially new test for the admission of evidence under s. 24(2), claiming that he was simply re-articulating established points of law. This is particularly problematic given that they are concurring reasons on a point not even addressed by the majority in that case. Obviously, Supreme Court justices are free to disagree with precedent; this is how law develops. It is suggested, however, that such disagreement ought to be done openly and always with strong supporting reasons. When there are policy considerations, as there nearly always are, these ought to be openly addressed and admitted. This is especially true in the context of a concurring judgment because of the great potential to cause confusion in lower courts as to the state of the law. Justice LeBel's judgment in Orbanski has set the stage for a renewed argument surrounding the admission of illegally obtained conscriptive evidence; however, it has done so by opening a back-door as it were, giving lower courts a vehicle for taking a position that would otherwise be extremely difficult to justify.

\section{GRANT: INTERPRETING ORBANSKI}

In the case of Grant, the Court of Appeal for Ontario has recently interpreted the reasons of LeBel J. as an expansion of the s. 24(2) doctrine on conscriptive evidence. As demonstrated above, the test set out by LeBel J. (in a concurring judgment) is significantly different than the test previously set out by the majority of the Supreme Court for the admission of conscriptive evidence. This means that in Ontario, at least, there is prima facie binding authority for a test for the admission of conscriptive evidence that is different than that test set out by the Supreme Court which is binding to the rest of the nation. In Grant. after finding a Charter breach, Laskin J.A. turned his mind to the issue of exclusion under s. 24(2) and held as follows:

[T] he revolver should be classified as conscriptive real evidence.

The question then becomes whether this conclusion ends the s. 24(2) inquiry. I do not think that it should. or that it does in this case. I think it is fair to say that up until now, trial and provincial appellatc courts have viewed the Supreme Cour of Canada's jurisprudence on s. 24(2), especially Sillmon. as standing for the proposition that conscriptive or derivative evidence affecting the faimess of the trial will be excluded in all, or virtually all, cases without consideration of the other two Collins factors. 
This so-called "automatic exclusionary rule", or near automatic exclusionary rule, has been the subject of strong academic criticism and, respectfully, does not seem fairhful to the longtuge of s. 24(2) itself. which directs the court to consider "all the circumstances" bearing on the repute of the justice system....

The most pertinent recent case is $R$. v. Elias; $R$. $v$. Orbanski, where, in concurring reasons, Lel3el J., writing for himself and Fish J., cautioned at para. 93 that the Court had not established a pure exclusionary rule for conscriptive evidence....

It seems to me that this passage reflects three important propositions. First, the admission of all conscriplive evidence, including derivative evidence, will have some impact on trial faimess. Second, if we do not have an automatic exclusionary rule for conscriptive evidence, then we must recognize that even though the admission of conscriptive evidence compromises trial faimess, its admission will not always bring the administration of justice into distepule. And third, whether conscriptive evidence should he admitted will depend both on the resulting degree of trial unfaimess and on the strength of the other fwo Collins factors.

Thus, be fore considering the other two Collins factors. I will focus on the criteria that might be used to assess the impact on trial fuimess resulting from the admission of conscriplive evidence. Although there may be others, two criteria that immediately come to mind are the potential elreet of the state's misconduct on the reliability of the evidence, and the nature of the police's conduct that led to the accused's participation in the production or obtaining of the evidence. ${ }^{156}$

To summarize Laskin J.A.'s articulation of the s. 24(2) test:

A near automatic exclusionary rule for conscriptive evidence is not tenable because it is not faithful to the language of s. 24(2);

Even if the admission of conscriptive evidence impacts trial fairness it does not necessarily bring the administration of justice into disrepute;

Thus, the other two Collins branches must be considered even with conscriptive evidence that impacts trial faimess; and

The degree of impact on fairness depends on, among other things, the reliability of the evidence and the nature of the police conduct.

There is no recognition of the general rule that conscriptive evidence gencrally impacts on trial fairness and that when trial fairness is impacted the administration of justice is necessarily brought into disrepute. The only exception is when the breach is technical or minor, and here trial fairness is not impacted at all. There is no recognition of the holding that the cause of the unfairness is not the reliability of the evidence or the blameworthiness of the police conduct, but the violation of the cornerstone right against self-incrimination: a person cannot be compelled (conscripted) to produce evidence against himself at his own trial if the trial is to be fair. 
If Laskin J.A. has articulated the correct interpretation of Orbanski, then Orbanksi can only be seen as contradictory to the reasons of Cory J. in Stillman. The "reliability" approach to evaluating the effect of conscriptive evidence on trial fairness is nearly exactly that endorsed by L'Heureux-Dubé J. in dissent in Burlingham, the very interpretation that occasioned such vehement disagreement with Sopinka and Cory JJ. The Supreme Court of Canada decided this issue directly in Stillman and the doctrine proposed by L'Heureux-Dubé J. was not accepted. Now, in a concurring judgment that was, strictly speaking, unnecessary for the outcome of the case, LeBel J. has successfully opened a door that was securely and deliberately shut by the Supreme Court over ten years ago. A more even-handed interpretation of Orbanski is that it is to be confined to its facts: it is one example among many of the exception to the conscriptive evidence rule of exclusion as articulated in Stillman. Justice Laskin's interpretation, however, effectively utilizes a brief minority opinion of the Supreme Court of Canada, that of LeBel and Fish JJ. in Orbanski, to overrule an established majority opinion, that of Cory J. in Stillman, and establishes elements of a rejected dissenting judgment, that of L'Heureux-Dube in Burlingham, as law in Ontario. If this analysis is correct, theoretically there is still room to argue that Laskin J.A.'s judgment in Grant is incorrect. In practice, however, lower courts will likely consider themselves bound by his reasons; indeed, anecdotal evidence suggests that Grant has caused a significant shift in the litigation of s. 24(2) in Ontario's trial courts. ${ }^{157}$ Moreover, given the respected status of Laskin J.A. as a Canadian jurist, his reasoning is sure to be noticed across Canada.

\section{Conclusion}

The desire for reform of the law on s. 24(2) is no surprise. Indeed, it "is likely that few Charter provisions have generated so much academic comment, conflicting jurisprudential developments, media rhetoric, or just plain uneasiness as s. $24(2) . " 15 k$ This is especially true for the conscriptive/non-conscriptive distinction which imparts a virtually automatic exclusionary rule into s. 24(2). However, such reform ought to be undertaken in an honest and principled fashion. There is a legitimate philosophical position that informs the Stillman approach to conscriptive evidence, and Cory J. set this out in detail in his reasons. Likewise, there is a strong argument to be made that the "fair trial dichotomy" is bad criminal law policy. If this issue is to be revisited, the Supreme Court of Canada has an obligation to outline the policy reasons that underlic its decision, admit that a change is taking place, and explain why such a change is necessary.

Academically honest reasons are a satisfying occurrence, even when one does not agree with them. Consider the following statements:

15. Sec c.g. R. r. I/am, 2006 ONCJ 426, 71 W.C.B. (2d) 729 at para. $29 ;$ R. v. Chen, 2006 ONCJ 419,71 W.C.B. (2d) 737 al para. 33; R. v. Mc.Murroy (2006), 38 M.V.R. (5th) is at para. 26: R. v. Pincy, 2006 ONCJ 380, 71 W.C.B. (2d) 154 at 31: $R$. v. Peglor, 2006 ONCJ 207, 70 W.C.13. (2d) 201 at para. 61: "The decisions in Orbansk $i$ und Gram/ have served to validate a more recent judicial shilt in its approach to the exclusion of conseriptive evidence." See also $R$. v. Shepherd, 2007 SKCA 29, [2007] 4 W.W.R. 659 for an opinion opposing the application of Gram and Orbauski. 
[W]e should never lose sight of the fact that even a person accused of the most heinous crimes, and no matter the likelihood that he or she actually committed those crimes, is entilled to the full protection of the Charter. Short-cutting or short-circuiting those rights affects not only the accused, but also the entire reputation of the criminal justice system. It must be emphasized that the goals of preserving the integrity of the criminal justice system as well as promoting the decency of investigatory techniques are of fundamental importance in applying $s .24(2) .^{159}$

If the exclusion of this evidence is likely to result in an acquittal of the accused as suggested by L'HeureuxDube J. in her reasons, then the Crown is deprived of a conviction based on illegally obtained evidence. Any price to society oceasioned by the loss of such a conviction is fully justified in a free and demoeratic society which is govemed by the rule of law. ${ }^{\text {tho }}$

Such candour is always to be expected, but is rarely delivered.

The policy discussion surrounding s. $24(2)$ is necessarily complex: as such, a detailed analysis will not be attempted here. There may very well be good reasons, logical, philosophical, or otherwise, to redevelop portions of the doctrine surrounding s. 24(2). It is clear, though, that this renewal must not be done in the name of the "original intention" behind s. 24(2). A progressive interpretation of aggressive exclusion is necessary in order to ensure that Charter values are recognized in the Canadian criminal justice system.

When embarking on the necessary analysis of legal policy, the virtues of progressive and liberal Charter interpretation must not be made subservient to confusing notions of original intentions or plain meaning. Stillman is consistent with the "plain meaning" of s. 24(2). Arguments against Stillman cannot therefore be based on a plain meaning attack with no examination of the underlying policy concerns. The Supreme Court of Canada, if it is indeed to change its s. 24(2) doctrine, ought to honestly and thoroughly address the policy issues at hand. As the Orbanski decision demonstrates, it is tempting and easy to incrementally overrule Stillman in the name of the intention and plain meaning of the section without ever dealing with its core argument.

If the Supreme Court is eventually to endorse a less exclusionary regime, thorough reasons ought to be provided so that the Canadian community can know in reality what philosophy is the impetus for change. The police are either assumed trustworthy until proved otherwise, or their power is viewed with skepticism. The rights of the individual are either paramount, or they are often trumped in the name of the majority. Is aggressive prosecution resulting in conviction necessary for justice to be done? Or must the justice system itself refuse to condone illegal state activity, even at the cost of a conviction? Which method best serves the interests of justice in the end? It is no secret that a civil libertarian world view underlies the Stillman approach to s. 24(2). It is a view that has been frequently and powerfully argued; it is an argument that demands a response. The majority in Stillman sees the right against self-incrimination as paramount and therefore central to a fair trial. This right is impugned 
when the illegally obtained evidence is conscriptive and not otherwise discoverable; its admission would render the trial unfair, and unfair trials bring the administration of justice into disrepute. The articulation of the law in Orbanski and Grant must fail because neither case meaningfully responds to the important policy issues at stake. The Stillman doctrine is simply rejected out of hand and its underlying rationale is entirely ignored. The doctrine as developed is not perfect; there may be many valid reasons why it ought to be revisited and changed. If courts are to embark on such a mission, however, intellectual honesty demands that the new doctrine be thoroughly supported by policy considerations that are fully articulated. It is tempting but unprincipled to initiate a s. 24(2) revolution incrementally without explaining why the decision reached by the majority in Stillman ought to be modified. 